\title{
Three-Component Coupling of Aldehydes, Amines, and Alkynes Catalyzed by Oxidized Copper Nanoparticles on Titania
}

\author{
María José Albaladejo, ${ }^{[a]}$ Francisco Alonso, ${ }^{*[a]}$ Yanina Moglie, ${ }^{[a]}$ and Miguel Yus ${ }^{[a]}$
}

\author{
Dedicated to the memory of Professor Balbino Mancheño
}

Keywords: Multicomponent reactions / Nanoparticles / Copper / Alkynes / Aldehydes / Amines

Copper nanoparticles (mainly as $\mathrm{Cu}_{2} \mathrm{O}$ ) on titania have been shown to catalyze the multicomponent synthesis of propargylamines from aldehydes, amines, and alkynes $\left(\mathrm{A}^{3}\right.$ coupling) effectively at $70{ }^{\circ} \mathrm{C}$ under solvent-free conditions. Both aromatic and aliphatic aldehydes and alkynes have been combined with secondary amines to provide a wide range of propargylamines in moderate to excellent yields. Two exam- ples of ketone/amine/alkyne $\left(\mathrm{KA}^{2}\right)$ coupling are also included. The catalyst is easy to prepare, reusable at a low copper loading ( $0.5 \mathrm{~mol}-\%)$, and exhibits higher catalytic activity than some commercially available copper sources. Some mechanistic aspects of the reaction have also been examined, which have unveiled the participation of copper(I) acetylides in a heterogeneous process.

\section{Introduction}

Propargylamines are a versatile class of compounds extensively applied as precursors in the synthesis of heterocyclic compounds such as quinolines, ${ }^{[1 \mathrm{a}]}$ phenanthrolines, ${ }^{[1 \mathrm{~b}]}$ pyrroles, ${ }^{[1 \mathrm{c}]}$ pyrrolidines, ${ }^{[1 \mathrm{~d}]}$ indolizines, ${ }^{[1 \mathrm{e}]}$ or oxazolidinones, ${ }^{[1 f]}$ among others. ${ }^{[2]}$ They have also been utilized as intermediates in the total synthesis of some natural and pharmaceutical products. ${ }^{[3]}$ Moreover, some propargylamine derivatives have been confirmed to be potent anti-apoptotic agents that protect neurons against cell death in cellular and animal models of neurodegenerative disorders. Indeed, they have been shown to delay the need for symptomatic therapy in untreated Parkinson's disease patients, results consistent with a neuroprotection role for compounds of this type. ${ }^{[4]}$

Conventional methods for the formation of the propargylamine moiety include direct amination of propargyl halides, ${ }^{[5]}$ triflates, ${ }^{[5 b]}$ phosphates, or acetates, ${ }^{[5 \mathrm{c}]}$ or the more widely practiced addition of alkynylmetal reagents to imines. ${ }^{[6]}$ The latter approach, normally involving stoichiometric amounts of lithium or magnesium acetylides, requires strict control of the reaction conditions and lacks atom economy, and its application is precluded in the presence of the more reactive functional groups. In recent years, metal-catalyzed coupling of aldehydes, amines, and alkynes

[a] Departamento de Química Orgánica, Facultad de Ciencias and Instituto de Síntesis Orgánica (ISO), Universidad de Alicante, Apdo. 99, 03080 Alicante, Spain

Fax: +34-965903549

E-mail: falonso@ua.es

Supporting information for this article is available on the WWW under http://dx.doi.org/10.1002/ejoc.201200090.
( $\mathrm{A}^{3}$ coupling) has emerged as a powerful tool that enables the direct addition of alkynes to imines (generated in situ) in a multicomponent and more efficient manner. ${ }^{[7]}$

The catalytic activation of the $\mathrm{C}-\mathrm{H}$ bond of terminal alkynes has been primarily achieved with complexes or salts of the late transition metals (e.g., Ir, $\mathrm{Zn}, \mathrm{Fe}, \mathrm{Co}, \mathrm{Ni}, \mathrm{Ag}$, $\mathrm{Au}, \mathrm{Ir}, \mathrm{Ru}$, but also In), but by far the most studied metal has been copper, especially with secondary amines. ${ }^{[7]}$ However, the majority of the catalytic systems are homogeneous, making the recovery and recycling of the catalyst troublesome. Nowadays, nanocatalysis is considered a sustainable and competitive alternative to conventional catalysis, because the metal nanoparticles possess a high surface-to-volume ratio, which enhances their activity and selectivity, at the same time maintaining the intrinsic features of a heterogeneous catalyst. ${ }^{[8]}$ In particular, the immobilization of metal nanoparticles on high-surface-area inorganic supports allows better stability and dispersity of the particles as well as a further exploitation of the special activity and recycling properties of the catalyst. ${ }^{[9]}$

To the best of our knowledge there are two reports that describe the use of copper nanoparticles (CuNPs) in $\mathrm{A}^{3}$ coupling: a) $\mathrm{Cu}^{0} \mathrm{NPs}(18 \pm 2 \mathrm{~nm})$, prepared in the aqueous core of reverse micellar droplets, were applied at $15 \mathrm{~mol}-\%$ in $\mathrm{MeCN}$ at $100-110{ }^{\circ} \mathrm{C}$ under nitrogen and were reutilized five times $(94-61 \%),{ }^{[10 a]}$ and b) nanocrystalline $\mathrm{CuO}$ was used at $10 \mathrm{~mol}-\%$ in toluene at $90{ }^{\circ} \mathrm{C}$ and reutilized four times $(82-76 \%) \cdot{ }^{[10 b]}$ Although the heterogeneous catalysts studied in $\mathrm{A}^{3}$ coupling generally exhibit good reuse capability, there are still some drawbacks that limit their acceptance, such as the high prices of the catalysts (especially 
those derived from noble metals) and their tedious preparation. In addition, some protocols involve environmentally unfriendly solvents, harsh conditions, long reaction times, and the need for inert atmospheres. The quest for new and more efficient catalysts for the synthesis of propargylamines based on $\mathrm{A}^{3}$ coupling is therefore still a subject of interest in synthetic organic chemistry.

As a part of our investigations into the reactivity of active metals and nanoparticles, ${ }^{[1]}$ a form of active copper was obtained from $\mathrm{CuCl}_{2} \cdot 2 \mathrm{H}_{2} \mathrm{O}$, lithium metal, and a catalytic amount of 4,4'-di-tert-butylbiphenyl (DTBB) in THF at room temperature and applied in reductions of a range of organic functionalitites. ${ }^{[12]} \mathrm{We}$ discovered that copper nanoparticles (CuNPs) were formed either from $\mathrm{CuCl}_{2}$. $2 \mathrm{H}_{2} \mathrm{O}$ or from anhydrous $\mathrm{CuCl}_{2}$ under these conditions. Unsupported CuNPs, generated from anhydrous $\mathrm{CuCl}_{2}$, were found to catalyze 1,3-dipolar cycloadditions of organic azides and terminal alkynes in remarkably short reaction times. ${ }^{[13]} \mathrm{A}$ second generation of catalysts was introduced through the immobilization of the CuNPs on different inorganic supports. In particular, we developed a highly versa-

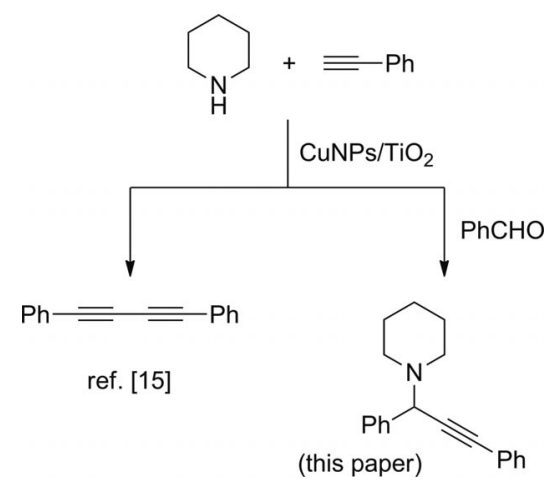

Scheme 1. Homocoupling of phenylacetylene and $\mathrm{A}^{3}$ coupling catalyzed by $\mathrm{CuNPs} / \mathrm{TiO}_{2}$. tile and reusable catalyst, consisting of oxidized copper nanoparticles on activated carbon $(0.5 \mathrm{~mol}-\% \mathrm{CuNPs} / \mathrm{C})$, for the multicomponent synthesis of 1,2,3-triazoles from organic halides, aryldiazonium salts, anilines, and epoxides in water. ${ }^{[14]} \mathrm{A}$ catalyst based on oxidized copper nanoparticles on titania ( $1 \mathrm{~mol}-\% \mathrm{CuNPs} / \mathrm{TiO}_{2}$ ) for the homocoupling of terminal alkynes in THF or under solventless conditions at $65^{\circ} \mathrm{C}$ in the presence of piperidine $(30 \mathrm{~mol}-\%)$ as a base has recently been reported. ${ }^{[15]}$ As part of our research into organic reactions promoted by CuNPs, here we wish to present our results on the performance and scope of supported CuNPs in the three-component coupling of aldehydes, amines, and alkynes under solvent-free conditions (Scheme 1).

\section{Results and Discussion}

\section{Preparation and Screening of the Catalysts}

The copper catalysts were prepared by addition of a variety of inorganic supports to a suspension of the recently prepared CuNPs, readily generated in turn from anhydrous copper(II) chloride, lithium metal, and a catalytic amount of DTBB $(10 \mathrm{~mol}-\%)$ in THF at room temperature. The supported catalysts were not subjected to any treatment prior to use. Firstly, a screening was carried out in order to optimize the catalyst support, solvent, and conditions, with the coupling of benzaldehyde (1a), piperidine (2a), and phenylacetylene (3a) as a model reaction (Table 1). A control experiment at $70{ }^{\circ} \mathrm{C}$ in the absence of catalyst did not give the expected product, irrespective of the solvent used (Table 1, Entry 1). In general, all the catalysts were quite effective in $\mathrm{CH}_{2} \mathrm{Cl}_{2}$, with the exception of $\mathrm{CuNPs} / \mathrm{TiO}_{2}$ (Table 1, Entry $5 / \mathrm{CH}_{2} \mathrm{Cl}_{2}$ ). The best results were achieved with $\mathrm{CuNPs} / \mathrm{C}$ (Table 1, Entry $2 / \mathrm{CH}_{2} \mathrm{Cl}_{2}$ ), either at 70

Table 1. Optimization of the support, solvent, and reaction conditions. ${ }^{[\mathrm{a}]}$

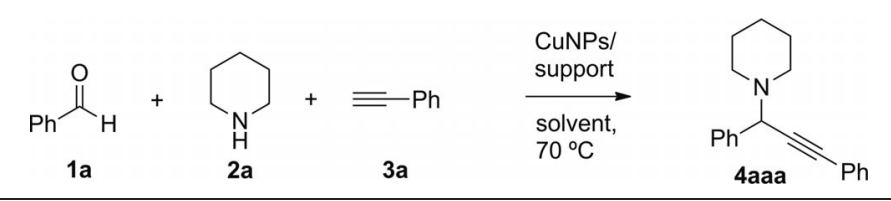

\begin{tabular}{|c|c|c|c|c|c|c|c|c|c|}
\hline Entry & Catalyst $^{[\mathrm{b}]}$ & THF & $\mathrm{H}_{2} \mathrm{O}$ & $\mathrm{EtOH}$ & $\mathrm{PhMe}$ & $\mathrm{CH}_{2} \mathrm{Cl}_{2}$ & $\mathrm{MeCN}$ & Acetone & Neat \\
\hline 1 & none & - & - & - & - & - & - & - & 3 \\
\hline 2 & $\mathrm{CuNPs} / \mathrm{C}$ & 70 & 7 & 23 & - & $98[90]^{[\mathrm{c}]}$ & - & - & 82 \\
\hline 3 & CuNPs/G & 25 & 6 & 8 & 4 & $96[47]^{[\mathrm{c}]}$ & 5 & - & 51 \\
\hline 4 & CuNPs/ZY & 25 & 2 & - & 2 & $92[89]^{[\mathrm{c}]}$ & 3 & - & 60 \\
\hline 5 & $\mathrm{CuNPs} / \mathrm{TiO}_{2}$ & 22 & 7 & 24 & 32 & 27 & - & - & $98[35]^{[\mathrm{d}]}$ \\
\hline 6 & $\mathrm{CuNPs} / \mathrm{ZnO}$ & 14 & 11 & - & 8 & $94[75]^{[\mathrm{c}]}$ & - & - & 72 \\
\hline 7 & CuNPs/MK & - & - & 8 & 21 & 85 & 18 & - & 48 \\
\hline 8 & $\mathrm{CuNPs} / \mathrm{SiO}_{2}$ & 32 & 6 & 31 & 21 & $92[47]^{[\mathrm{c}]}$ & 4 & - & 57 \\
\hline 9 & CuNPs/MS & 38 & 4 & 44 & 13 & 86 & 42 & - & - \\
\hline 10 & CuNPs/MgO & 3 & 3 & 12 & 7 & $87[47]^{[\mathrm{c}]}$ & 6 & - & 75 \\
\hline
\end{tabular}

[a] Reaction conditions: 1a $(1.0 \mathrm{mmol}), \mathbf{2 a}(1.0 \mathrm{mmol}), \mathbf{3 a}(1.0 \mathrm{mmol}), \mathrm{CuNPs} / \mathrm{support}(20 \mathrm{mg})$, solvent $(2 \mathrm{~mL}), 70{ }^{\circ} \mathrm{C}$; numbers in each solvent column refer to conversion into 4 aaa after $24 \mathrm{~h}$, determined by GC. [b] C = activated carbon, $\mathrm{G}=$ graphite, $\mathrm{ZY}=$ sodium zeolite $\mathrm{Y}, \mathrm{MK}=$ montmorillonite $\mathrm{K}-10, \mathrm{MS}=$ molecular sieves $(4 \AA)$. [c] Reaction at $40^{\circ} \mathrm{C}$ in brackets. [d] Reaction at room temperature in brackets. 
$(98 \%)$ or at $40{ }^{\circ} \mathrm{C}(90 \%)$, although the level of conversion with CuNPs on zeolite $\mathrm{Y}$ at $40{ }^{\circ} \mathrm{C}(89 \%)$ is also worthy of mention (Table 1, Entry $4 / \mathrm{CH}_{2} \mathrm{Cl}_{2}$ ). Acetone, THF, $\mathrm{H}_{2} \mathrm{O}$, $\mathrm{EtOH}, \mathrm{PhMe}$, or $\mathrm{MeCN}$ were shown to be inappropriate solvents, with only THF providing a moderate degree of conversion into 4aaa in the presence of $\mathrm{CuNPs} / \mathrm{C}$ (Table 1, Entry 2/THF). All the catalysts were tested in the absence of solvent, with the observation of no conversion for $\mathrm{CuNPs} / \mathrm{MS}$, modest levels of conversion for CuNPs/G, $\mathrm{CuNPs} / \mathrm{ZY}$, CuNPs/MK, and $\mathrm{CuNPs} / \mathrm{SiO}_{2}$, moderate to good levels of conversion for CuNPs/C, CuNPs/ZnO, and $\mathrm{CuNPs} / \mathrm{MgO}$, and excellent levels of conversion for CuNPs/ $\mathrm{TiO}_{2}$ (Table 1, neat). Unfortunately, low levels of conversion were observed in the latter case when the reaction was carried out at room temperature (Table 1, Entry 5/neat). Because solvent-free organic synthesis is one of the most promising steps for waste prevention and environmental protection, ${ }^{[16]}$ we selected $\mathrm{CuNPs} / \mathrm{TiO}_{2}$ at $70{ }^{\circ} \mathrm{C}$ under solvent-free conditions as the catalyst of choice, to the detriment of the potentially good performance of $\mathrm{CuNPs} / \mathrm{C}$ in $\mathrm{CH}_{2} \mathrm{Cl}_{2}$ at $40^{\circ} \mathrm{C}$.

\section{Characterization of the Catalyst ${ }^{[15]}$}

The $\mathrm{CuNPs} / \mathrm{TiO}_{2}$ catalyst had previously been characterized by different means including TEM, X-ray photoelectron spectroscopy (XPS), and powder XRD, among others. Analysis by TEM revealed the presence of well-defined and dispersed spherical nanoparticles with diameters of ca. $1.0 \pm 0.4 \mathrm{~nm}$ on the titania. Auger analysis complemented the data obtained from XPS, denoting primarily the presence of $\mathrm{Cu}_{2} \mathrm{O}$. A copper content of $3.0 \mathrm{wt} .-\%$ in the catalyst was determined by inductively coupled plasma mass spectrometry (ICP-MS). This content corresponds to 1 mol- $\% \mathrm{Cu}$ with respect to the substrates in the $\mathrm{A}^{3}$ coupling, but only $0.47 \mathrm{~mol}-\%$ (ca. $0.5 \mathrm{~mol}-\%$ ) with allowance for the fact that the copper is mainly in the form of copper(I) oxide. This catalyst loading is considerably lower than those previously reported with other catalytic systems based on CuNPs (10-15 mol-\%). ${ }^{[10]}$

\section{Three-Component Coupling of Aldehydes, Amines, and Alkynes Catalyzed by $\mathrm{CuNPs} / \mathrm{TiO}_{2}$}

All reactions were performed with ca. 0.5 mol- $\%$ CuNPs/ $\mathrm{TiO}_{2}$ at $70{ }^{\circ} \mathrm{C}$ in the absence of solvent. A control experiment under the above conditions but in the presence only of titania (without copper) gave no trace of the corresponding propargylamine after $24 \mathrm{~h}$. This result confirms the essential role of copper and practically rules out any catalytic effect of the support.

A series of commercially available aldehydes, secondary amines, and alkynes were subjected to the title reaction (Table 2). Firstly, benzaldehyde (1a) and phenylacetylene (3a) were coupled with different cyclic amines such as piperidine (2a), morpholine (2b), and 4-methylpiperidine (2c), leading to $\mathbf{4 a a}$ and $\mathbf{4 a b a}$ in high yields, and $\mathbf{4 a c a}$ in moderate yield, respectively. Propargylamine 4ada, derived from 2-methylpiperidine (2d), required prolonged heating and was obtained with moderate diastereoselectivity, whereas $\mathrm{N}$ methylbenzylamine (2e) reacted more rapidly and with higher conversion into 4aea.

Next, the nature of the alkyne was modified with the aldehyde and the amine kept constant. Arylacetylenes bearing either electron-donating (4aab) or electron-withdrawing groups (4aac) were examined, with the latter giving some side reactions; cyclohexylacetylene furnished $\mathbf{4 a a d}$ in a yield intermediate between those of $\mathbf{4 a a b}$ and $\mathbf{4 a a c}$. The structure of the aldehyde seemed to have more pronounced effects both on the reaction time and on the isolated yield. Longer reaction times and lower yields were observed for the derivatives of 4-methoxybenzaldehyde (4baa) and 2-napththaldehyde (4eaa), for instance, whereas much better results were achieved with 2-iodobenzaldehyde (4caa), 3-nitrobenzaldehyde (4daa), and benzofuran-2-carbaldehyde (4faa). Several aliphatic aldehydes were then subjected to the $\mathrm{A}^{3}$ coupling. Decanal (4g) and cyclohexanecarbaldehyde (4h), when coupled with piperidine (2a) and phenylacetylene (3a), afforded the propargylamines 4gaa and 4haa in high yields, though the reaction time was much shorter in the second case. $N$-Methylaniline (2f) and $N$-methyl- $\alpha$-methylbenzylamine ( $\mathbf{2 g}$ ) behaved similarly in reactions with cyclohexanecarbaldehyde (4h) and phenylacetylene (3a), with the products $\mathbf{4 h f a}$ and 4 hga being obtained in good yields but with low diastereoselectivity in the latter case. An alkyl- and cycloalkyl-substituted propargylamine (4hae) could be also prepared in high yield. We were delighted to see that even the simplest aldehyde, formaldehyde (1i, $37 \%$ in $\mathrm{H}_{2} \mathrm{O}$ / $\mathrm{MeOH}$ solution), reacted nicely with diethylamine (2h) and phenylacetylene (3a), thus giving access to a propargylamine unsubstituted at the propargyl position (4iha). $(S)-(-)$-Citronellal (4j) was coupled with piperidine (2a) and phenylacetylene (3a), with the expected product 4jaa being obtained in a relatively short reaction time, in a high yield, and with some diastereoselectivity. In this case, the two diastereoisomers could be separated by column chromatography.

In view of the low to moderate diastereoselectivities observed for 2-methylpiperidine (2d) and $N$-methyl- $\alpha$-methylbenzylamine (2g), we speculated that use of proline derivatives might give better results. Indeed, $(R)$-2-(methoxymethyl)pyrrolidine (2i, Scheme 2) afforded the benzaldehyde derivative 4aia in $84 \%$ yield and 94:6 $d r$, this ratio matching the values obtained for ent-4aia with other methodologies. ${ }^{[17]}$ A slightly lower isolated yield and diastereoselectivity were recorded when decanal was used as the aldehyde (Scheme 2, compound 4gia). In this case, the relative $(R, R)$ stereochemistry assigned for the major diastereoisomer was established by correlation of the chemical shifts of the $\mathrm{NCH}$ propargylic hydrogen atoms in the two diastereoisomers with those of 4aia. Finally, it is noteworthy that the coupling of benzaldehyde (1a), piperidine (2a), and phenylacetylene (3a) was demonstrated to be scalable to $5 \mathrm{mmol}$, giving rise to propargylamine 4aaa in $67 \%$ isolated yield. 
Table 2. Three-component coupling of aldehydes, amines, and alkynes catalyzed by $\mathrm{CuNPs} / \mathrm{TiO}_{2} \cdot{ }^{[\mathrm{a}, \mathrm{b}]}$

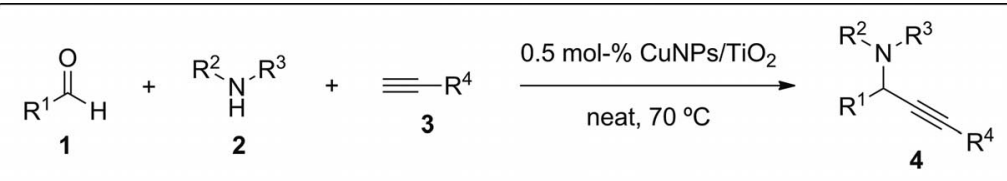
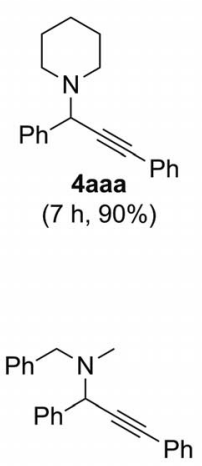

4aea

(7 h, $80 \%$ )<smiles>COc1ccc(C(C#Cc2ccccc2)N2CCCCC2)cc1</smiles>

(20 h, 61\%)
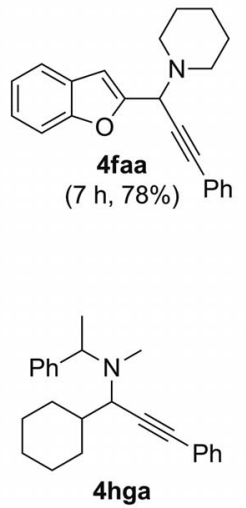

(20 h, 82\%)

$(d r 56: 44)^{[c]}$
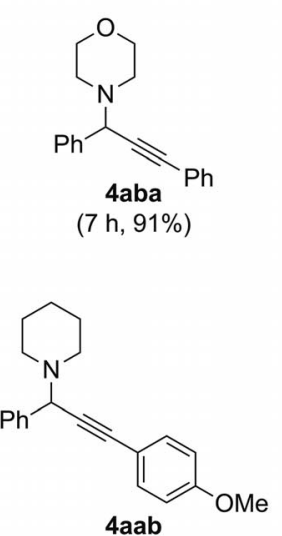

(20 h, 79\%)

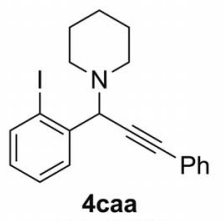

(4 h, 90\%)
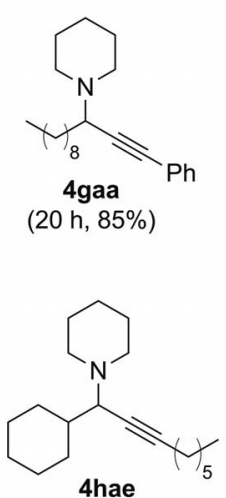

(20 h, 92\%)
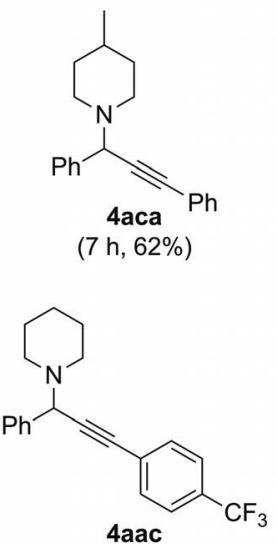

(20 h, 60\%)<smiles>O=[N+]([O-])c1cccc(C(C#Cc2ccccc2)N2CCCCC2)c1</smiles>

(17 h, 78\%)
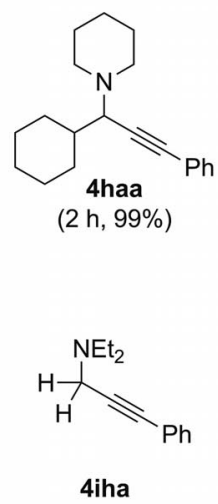

(20 h, 94\%)<smiles>CC1CCCCN1C(C#Cc1ccccc1)c1ccccc1</smiles>

4ada

(22 h, 67\%) $(d r \text { 88:15) })^{[\mathrm{c}]}$

(20 h, 70\%)<smiles>CC(C)(C)OC(=O)c1ccc2ccccc2c1</smiles>

(20 h, 52\%)<smiles>CN(c1ccccc1)C(C#CPc1ccccc1)C1CCCCC1</smiles>

(20 h, 80\%)

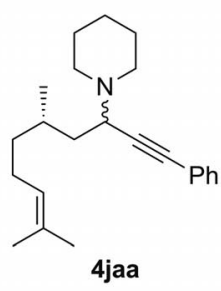

$(8 \mathrm{~h}, 88 \%)$

$(d r 72: 28)^{[\mathrm{C}]}$

[a] Reaction conditions: 1 (1.0 mmol), 2 (1.0 mmol), $3(1.0 \mathrm{mmol}), \mathrm{CuNPs} / \mathrm{TiO}_{2}(0.5 \mathrm{~mol}-\%)$, neat, $70{ }^{\circ} \mathrm{C}$. [b] Isolated yield. [c] Diastereomeric ratio measured by $\mathrm{GC}$ from the reaction crude.

\section{Stability and Recycling of the Catalyst}

The catalyst could be handled in air and all the experiments were carried out without air exclusion; these are advantages that make the process operationally simple. It is worth mentioning that, despite the fact of the small amount of catalyst utilized $(20 \mathrm{mg})$, it could easily be recovered by filtration (after addition of diethyl ether) and reused. Good catalyst performance in the coupling of benzaldehyde (1a), piperidine (2a), and phenylacetylene (3a) was observed over four consecutive cycles (Figure 1).

The copper level in the aqueous solution between cycles was detected to be $40 \mathrm{ppb}$ (ICP-MS), which practically rules out any loss of catalytic activity through metal leaching. More probably, loss of catalyst mass during filtration (through a fritted glass filter) could account for the decreas- 


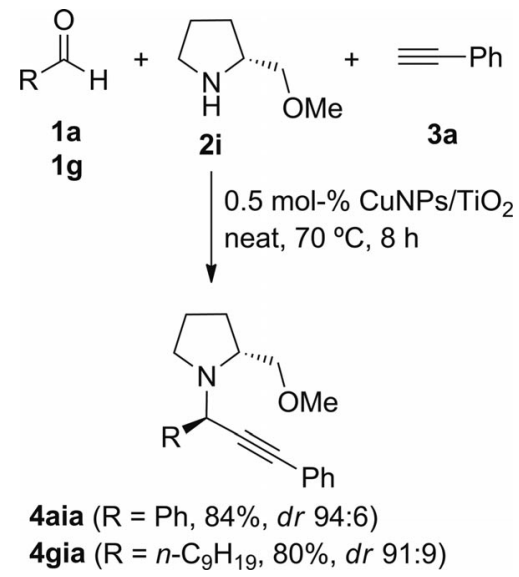

Scheme 2. Diastereoselective synthesis of propargylamines 4aia and 4gia.

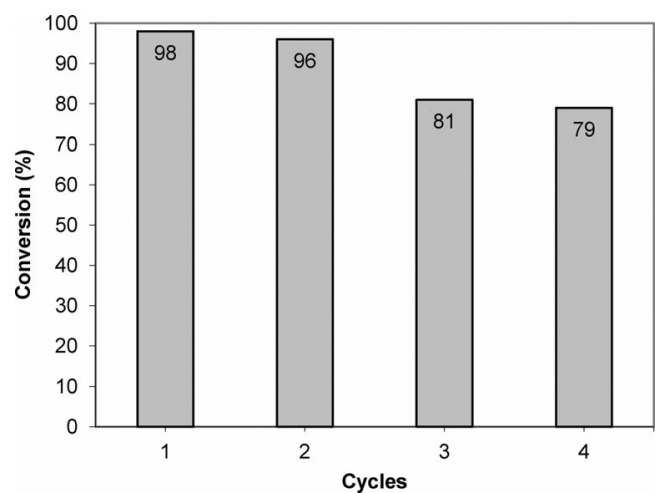

Figure 1. Recycling of $\mathrm{CuNPs} / \mathrm{TiO}_{2}$ in the synthesis of propargylamine 4aaa.

ing tendency in the conversion observed in the recycling experiments. Although the above analysis points to a process that is heterogeneous in nature, we cannot in principle dismiss the possibility that the support acts as a reservoir for metal species that leach into solution and readsorb. Processes of this kind, however, have mainly been shown to occur for nanoparticle suspensions of the catalytically active group VIII transition metals. ${ }^{[18]}$

\section{Comparison with Other Catalysts}

Any laboratory-made catalyst should, as a matter of principle, be more efficient than commercially available catalysts used for the same purpose, and so we undertook a comparative study of the reactivity of $\mathrm{CuNPs} / \mathrm{TiO}_{2}$ with those of different commercially available copper sources (Table 3). The standard conditions were applied to the reaction of benzaldehyde (1a), piperidine (2a), and phenylacetylene (3a) at different catalyst loadings. Copper metal, $\mathrm{CuO}$, and $\mathrm{Cu}_{2} \mathrm{O}(10 \mathrm{~mol}-\%)$ gave rise to the expected propargylamine 4aaa with moderate levels of conversion (Table 3, Entries 1-3). $\mathrm{CuCl}$ and $\mathrm{CuCl}_{2}$ (both at $10 \mathrm{~mol}-\%$ ) were the best commercial catalysts, although prolonged heating was necessary and the levels of conversion were not as high as desirable (Table 3, Entries 4 and 6). The levels of conversion for $\mathrm{CuCl}$ and $\mathrm{CuCl}_{2}$ dropped when the catalyst loading was reduced to $1 \mathrm{~mol}-\%$, with concomitant formation of the diyne derived from 3a (Table 3, Entries 5 and 7). A similar trend was observed for $\mathrm{CuBr}$ and $\mathrm{CuI}$ at 1 mol$\%$ (Table 3, Entries 8 and 9). Therefore, the nanosized character of our catalyst and its distribution on the support seem to play decisive roles in its higher performance (Table 3, Entry 10). Furthermore, the easy catalyst preparation, lower metal loading, lower reaction temperature, lack of requirement for an inert atmosphere, and absence of solvent are some clear advantages with respect to other catalysts based on $\mathrm{CuNPs}^{[10]}$ or other heterogeneous catalysts. ${ }^{[7 \mathrm{~d}]}$

Table 3. Synthesis of propargylamine 4aaa catalyzed by different copper catalysts. ${ }^{[\mathrm{a}]}$

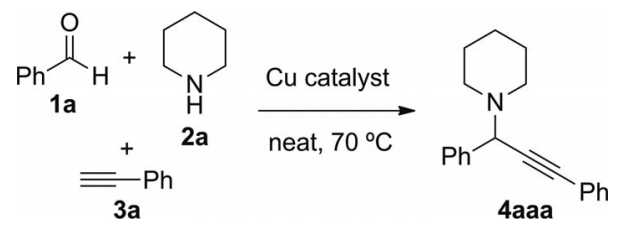

\begin{tabular}{llccc}
\hline Entry & $\mathrm{Cu}$ catalyst & {$[\mathrm{Mol}-\%]$} & $t[\mathrm{~h}]$ & ${\text { Conversion }[\%]^{[\mathrm{b}]}}^{\circ}$ \\
\hline 1 & $\mathrm{Cu}$ & 10 & 24 & 49 \\
2 & $\mathrm{CuO}$ & 10 & 24 & 55 \\
3 & $\mathrm{Cu} 2 \mathrm{O}$ & 10 & 24 & 63 \\
4 & $\mathrm{CuCl}$ & 10 & 24 & 80 \\
5 & $\mathrm{CuCl}$ & 1 & 24 & $63^{[\mathrm{c}]}$ \\
6 & $\mathrm{CuCl}_{2}$ & 10 & 24 & 76 \\
7 & $\mathrm{CuCl}_{2}$ & 1 & 24 & $64^{[\mathrm{c}]}$ \\
8 & $\mathrm{CuBr}$ & 1 & 24 & $51^{[\mathrm{d}]}$ \\
9 & $\mathrm{CuI}$ & 1 & 24 & $62^{[\mathrm{d}]}$ \\
10 & $\mathrm{CuNPs} / \mathrm{TiO}_{2}$ & 0.5 & 7 & 98 \\
\hline
\end{tabular}

[a] Reaction conditions: 1a $(1.0 \mathrm{mmol}), \quad \mathbf{2 a} \quad(1.0 \mathrm{mmol}), \quad \mathbf{3 a}$ $(1.0 \mathrm{mmol})$, catalyst, neat, $70^{\circ} \mathrm{C}$. [b] Levels of conversion determined by GC. [c] A $31 \%$ yield of the diyne derived from 3a was obtained. [d] 15-26\% yields of the diyne derived from 3a were obtained.

\section{Some Mechanistic Aspects}

Tentative mechanisms for copper-catalyzed $\mathrm{A}^{3}$ coupling have been proposed. They normally invoke the participation of copper acetylides, which react with the iminium ions generated in situ from the aldehydes and secondary amines to give the corresponding propargylamines. ${ }^{[19]}$ This class includes the mechanism reported by Lakshmi Kantam et al. when nanocrystalline $\mathrm{CuO}$ was used as catalyst. ${ }^{[10 b]}$ The mechanism depicted by Kidwai et al. however, is somewhat dubious because, on one hand, $\mathrm{Cu}^{0} \mathrm{NPs}$ seem to undergo oxidative addition to the alkyne to give a mixed copper hydride acetylide, followed by deprotonation to afford the copper acetylide. ${ }^{[10 a]}$ On the other hand, though, the authors suggested that the reaction might proceed through a free radical mechanism. 
We performed different experiments in order to gain an inside into the reaction mechanism of the $\mathrm{A}^{3}$ coupling catalyzed by CuNPs. We observed that the addition of radical traps such as norbornene, cumene, or 2,6-di-tert-butylphenol did not inhibit the standard reaction, and no products originated from their reaction with alkynyl radicals were detected. Use of TEMPO led to some side reactions, although its coupling with the alkyne moiety was not observed either. Because the presence of free radicals might compromise the existence of the (originally) formyl hydrogen atom in the product (tertiary benzylic and propargylic $\mathrm{N}-\mathrm{C}-\mathrm{H}$ ), two deuterium-labeling experiments were conducted (Scheme 3). The reaction of benzaldehyde (1a) with piperidine (2a) and deuterated phenylacetylene $\left(\mathrm{D}_{1}-\mathbf{3 a}\right)$ did not show any incorporation of deuterium into the product 4aaa (Scheme 3, a), whereas the coupling of deuterated benzaldehyde $\left(\mathrm{D}_{1}-\mathbf{1 a}\right)$ with piperidine (2a) and phenylacetylene (3a) yielded the propargylamine $\mathrm{D}_{1}$-4aaa with quantitative deuterium incorporation (Scheme 3, b). These results indicate that the reaction mechanism of the $\mathrm{A}^{3}$ coupling catalyzed by CuNPs very likely does not involve free radicals.

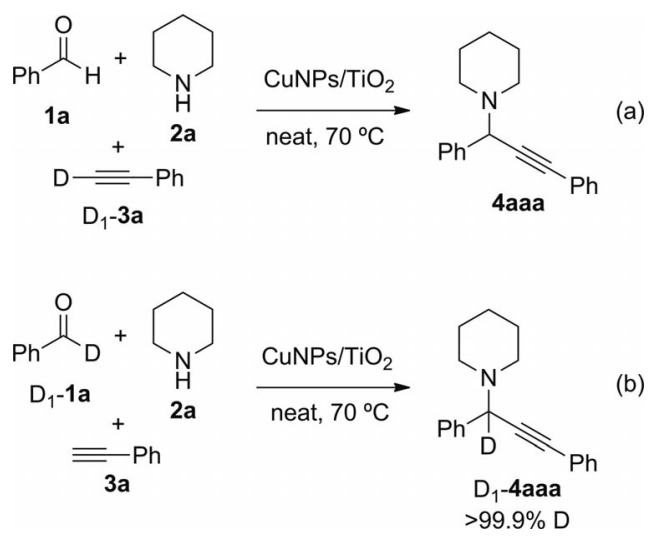

Scheme 3. Deuterium-labeling experiments in the $\mathrm{CuNPs} / \mathrm{TiO}_{2}$-catalyzed $\mathrm{A}^{3}$ coupling.

We have recently experimentally demonstrated that copper(I) acetylides are the true intermediate species in coppercatalyzed azide/alkyne cycloadditions involving unsupported CuNPs in the presence of triethylamine and THF as solvent. ${ }^{[13 \mathrm{~b}]}$ We also showed that, in the absence of base, CuNPs enhance the acidity of a terminal alkyne in water, by coordination to the carbon-carbon triple bond, thus enabling the formation of the corresponding copper(I) acetylide. When phenylacetylene was allowed to react with the CuNPs $/ \mathrm{TiO}_{2}$ catalyst at $70{ }^{\circ} \mathrm{C}$ a yellow color attributable to copper(I) phenylacetylide (5a) appeared over the support (Scheme 4). ${ }^{[20]}$ This organocopper compound displayed great stability and insolubility, not undergoing any noticeable change after exposure to air for several weeks. It is generally recommended that copper acetylides be preserved under inert atmosphere in the dark, so we cannot rule out a stabilization effect arising from the fact that $\mathbf{5 a}$ remains anchored to the heterogeneous catalyst $\left(\mathbf{5 a} / \mathrm{TiO}_{2}\right)$; some $\mathrm{Cu}-\mathrm{O}$ bonding between $\mathrm{Cu}$ atoms and the $\mathrm{O}$ of $\mathrm{TiO}_{2}$ has been reported on specific surfaces. ${ }^{[21]}$ When $\mathbf{5 a} / \mathrm{TiO}_{2}$ was washed with diethyl ether, in order to remove any trace of phenylacetylene, and warmed to $70{ }^{\circ} \mathrm{C}$, the corresponding diyne $6 \mathbf{a}$ was formed and the yellow color on the solid vanished. Addition of benzaldehyde (1a) and piperidine (2a) to that solid furnished the $\mathrm{A}^{3}$ product 4aaa together with a minor amount of diyne 6a. These experiments therefore imply that copper(I) acetylides are the true intermediates in this methodology and suggest a process that is heterogeneous in nature.

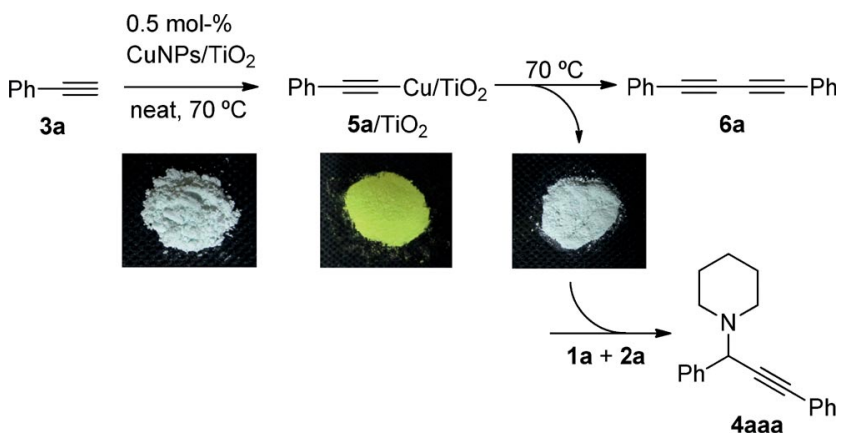

Scheme 4. Formation of copper(I) phenylacetylide from CuNPs/ $\mathrm{TiO}_{2}$.

On the basis of the experiments described above and our previous experience in acetylene chemistry and CuNPs, we propose an ionic reaction mechanism (Scheme 5) that includes: a) coordination of the alkyne to the CuNPs with concomitant activation of the $\mathrm{C}-\mathrm{H}$ bond, b) formation of the corresponding copper(I) acetylide on the titania support (the acetylenic hydrogen might form a hydroxy group with a surface oxygen atom or might be attached to a bridging oxygen of the support), ${ }^{[22]}$ and c) addition of the copper(I) acetylide to the iminium ion generated in situ from the aldehyde and the amine, with the subsequent formation of the propargylamine, water, and regeneration of the catalytically active species.

\section{The Ketone/Amine/Alkyne (KA $\left.{ }^{2}\right)$ Coupling}

Ketones are much more reluctant than aldehydes to react in the three-component reaction. In fact, the $\mathrm{KA}^{2}$ coupling remained unknown until the recent discovery by the group of Van der Eycken, in which microwave irradiation was found to assist this process with $\mathrm{CuI}$ catalysis $(20 \mathrm{~mol}-\%)$ at $100{ }^{\circ} \mathrm{C}$ in the absence of solvent. ${ }^{[23]}$ Only cyclohexanone and its derivatives were reported to be reactive enough to produce the expected propargylamines in moderate to good yields. More recently, a wider substrate scope has been achieved with the aid of gold catalysis. ${ }^{[24]}$ We studied the $\mathrm{CuNPs} / \mathrm{TiO}_{2}$-catalyzed $\mathrm{KA}^{2}$ coupling of cyclohexanone (1k Scheme 6) with piperidine (2a) and phenylacetylene (3a) and observed that, under the above solvent-free conditions, maximum yields of ca. $35 \%$ were recorded. The yields 


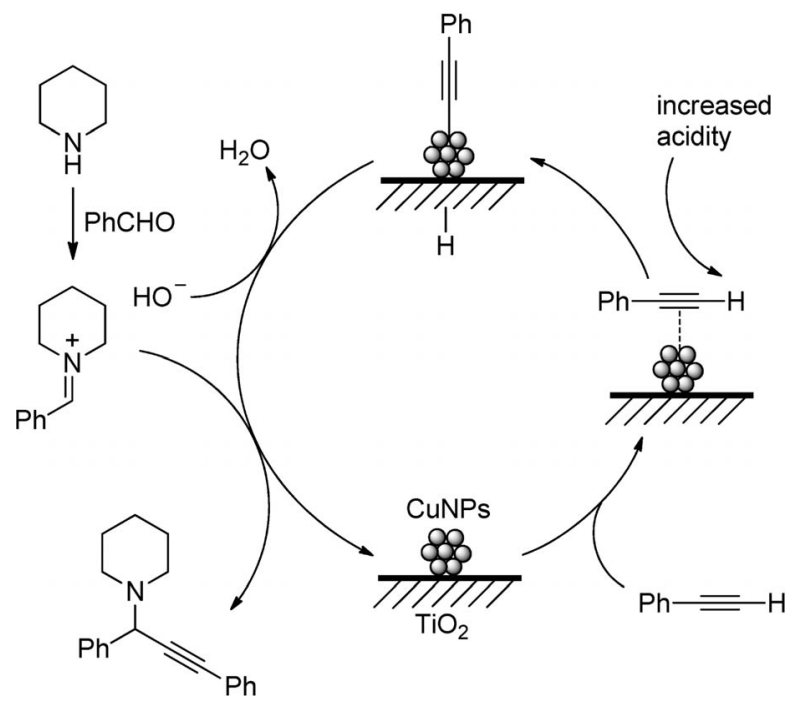

Scheme 5. Proposed reaction mechanism for the $\mathrm{A}^{3}$ coupling catalyzed by $\mathrm{CuNPs} / \mathrm{TiO}_{2}$.

could be substantially improved [also in the case of $N$-methylbenzylamine (2e)] by use of dichloromethane as solvent (Scheme 6). In contrast, pentan-3-one could be coupled with $N$-methylbenzylamine and phenylacetylene in only $30 \%$ yield, even with use of dichloromethane as solvent.

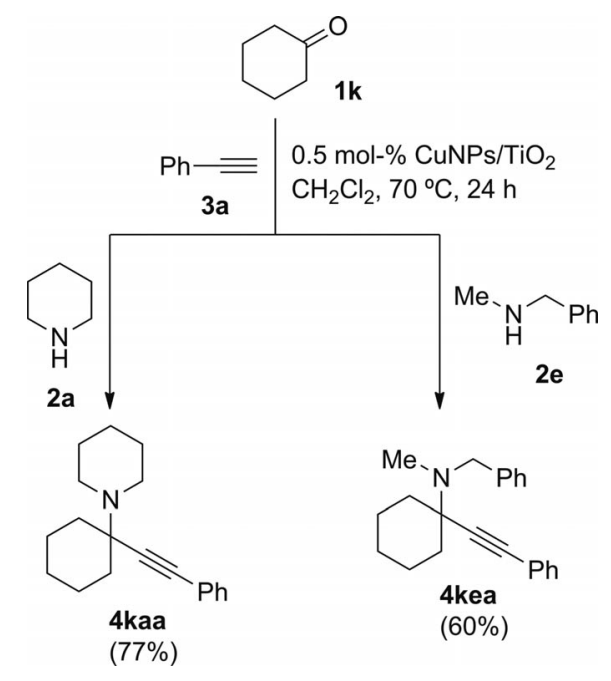

Scheme 6. $\mathrm{KA}^{2}$ coupling catalyzed by $\mathrm{CuNPs} / \mathrm{TiO}_{2}$.

\section{Conclusions}

A series of catalysts composed of copper nanoparticles on different supports have been tested in three-component couplings of aldehydes, secondary amines, and terminal alkynes. The $\mathrm{CuNPs} / \mathrm{TiO}_{2}$ catalyst, in which copper is present mainly as $\mathrm{Cu}_{2} \mathrm{O}$, manifested the best performance in this reaction at $70{ }^{\circ} \mathrm{C}$ under solvent-free conditions. An array of structurally different propargylamines has been synthesized, in moderate to excellent yields (52-99\%) and with low metal loadings $(0.5 \mathrm{~mol}-\%)$, from all sorts of aryl-, alkyl-, and cycloalkyl-substituted substrates. The catalyst could be recycled, with negligible leaching (40 ppb), and reused over four cycles, providing excellent to good yields of the product (98-79\%). Moreover, higher catalytic activity with less byproduct formation was observed for $\mathrm{CuNPs} / \mathrm{TiO}_{2}$ than for some commercial copper sources. In addition, two examples of ketone/amine/alkyne coupling have been reported, in this case in the presence of dichloromethane as solvent. Finally, different experiments ruled out a free-radical mechanism and unveiled the participation of copper(I) acetylides as reaction intermediates in a process that is heterogeneous in nature.

\section{Experimental Section}

General: Anhydrous copper(II) chloride (97\%, Aldrich), lithium powder (MEDALCHEMY S. L.), and DTBB (4,4'-di-tert-butylbiphenyl, Aldrich) were commercially available. Degussa $\mathrm{P} 25 \mathrm{TiO}_{2}$ ( $60 \%$ anatase, $40 \%$ rutile) with a surface area of $50 \mathrm{~m}^{2} \mathrm{~g}^{-1}$ was used as support, after being calcined in air at $500^{\circ} \mathrm{C}$ for $5 \mathrm{~h}$. All the starting materials and other reagents were commercially available of the best grade (Aldrich, Acros, Alfa Aesar) and were used without further purification. 1-Deuterio-2-phenylacetylene $\left(\mathrm{D}_{1}-\mathbf{3 a}\right)$ was prepared by stirring phenylacetylene (3a) and $\mathrm{D}_{2} \mathrm{O}$ at $70^{\circ} \mathrm{C}$ overnight, followed by a standard extraction workup. ${ }^{[14 \mathrm{c}]} 1$-Deuterio1-phenylmethanone $\left(\mathrm{D}_{1}-\mathbf{1 a}\right)$ was obtained from ethyl benzoate by reduction with $\mathrm{LiAlD}_{4}{ }^{[25]}$ (THF, $0{ }^{\circ} \mathrm{C}, 4 \mathrm{~h}$, room temp.) and oxidation with Dess-Martin's reagent $\left(\mathrm{CH}_{2} \mathrm{Cl}_{2}, 2 \mathrm{~h}\right.$, room temp.). THF was dried in a Sharlab PS-400-3MD solvent purification system with an alumina column. All reactions were carried out with a multireactor apparatus and the corresponding reactor tubes. Melting points were obtained with a Reichert Thermovar apparatus. Optical rotations were measured with a Perkin-Elmer 341 polarimeter with a thermally jacketed $5-\mathrm{cm}$ cell at approximately $20{ }^{\circ} \mathrm{C}$. Concentrations $(c)$ are given in $\mathrm{g} / 100 \mathrm{~mL}$ and $[\alpha]$ values are given in units of $10^{-1} \mathrm{deg} \mathrm{cm}^{2} \mathrm{~g}^{-1}$. NMR spectra were recorded with Bruker Avance 300 and 400 spectrometers (300 and $400 \mathrm{MHz}$ for ${ }^{1} \mathrm{H}$ NMR; 75 and $100 \mathrm{MHz}$ for ${ }^{13} \mathrm{C} \mathrm{NMR}$ ); peak assignments were achieved on the basis of DEPT experiments and estimation with the ACD/Laboratories 6.0 program; chemical shifts $(\delta)$ are given in parts per million and coupling constants $(J)$ in Hertz. Infrared analysis was performed with a Jasco 4100LE (Pike MIRacle ATR) spectrophotometer; wavenumbers $(\tilde{v})$ are given in $\mathrm{cm}^{-1}$. Mass spectra (EI) were obtained at $70 \mathrm{eV}$ with an Agilent 5973 spectrometer; fragment ions in $\mathrm{m} / \mathrm{z}$ with relative intensities (\%) in parentheses. HRMS analyses were also carried out in the electron impact mode (EI) at $70 \mathrm{eV}$ with a Finnigan MAT95S spectrometer. The purities of volatile compounds and the chromatographic analyses (GLC) were determined with a Hewlett-Packard HP-5890 instrument and an Agilent 5973 GC-MS apparatus. Retention times $\left(t_{\mathrm{R}}\right)$ were obtained with the latter under the following conditions: HP5MS capillary column $(30 \mathrm{~m}, 0.25 \mathrm{~mm}$ diameter, $0.25 \mu \mathrm{m}$ film thickness) with helium $\left(54.1 \mathrm{~mL} \mathrm{~min}^{-1}\right)$ as carrier gas, $T_{\text {injector }}=250{ }^{\circ} \mathrm{C}$, $T_{\text {column }}=60{ }^{\circ} \mathrm{C}(3 \mathrm{~min})$ and $60-270{ }^{\circ} \mathrm{C}\left(15^{\circ} \mathrm{Cmin}^{-1}\right)$. Column chromatography was performed with silica gel 60 of 40-60 microns (hexane/EtOAc as eluent).

Typical Procedure for the Preparation of $\mathrm{CuNPs} / \mathrm{TiO}_{2}$ : Anhydrous copper(II) chloride (135 mg, $1 \mathrm{mmol}$ ) was added at room temperature under argon to a suspension of lithium (14 mg, $2 \mathrm{mmol})$ and 4,4'-di-tert-butylbiphenyl (DTBB, $27 \mathrm{mg}, 0.1 \mathrm{mmol}$ ) in THF $(2 \mathrm{~mL})$. The reaction mixture, which was initially dark blue, rapidly 
changed to black, indicating that the suspension of copper nanoparticles had been formed. This suspension was diluted with THF $(18 \mathrm{~mL})$ followed by addition of $\mathrm{TiO}_{2}(1.28 \mathrm{~g})$. The resulting mixture was stirred for $1 \mathrm{~h}$ at room temperature and filtered, and the solid was washed with THF $(20 \mathrm{~mL})$ and dried under vacuum.

General Procedure for the $\mathrm{A}^{3}$ Coupling Catalyzed by $\mathrm{CuNPs} / \mathrm{TiO}_{2}$ : The aldehyde 1 (1.0 $\mathrm{mmol})$, amine $2(1.0 \mathrm{mmol})$, and alkyne 3 $(1.0 \mathrm{mmol})$ were placed in a reactor tube containing $\mathrm{CuNPs} / \mathrm{TiO}_{2}$ (20 mg, ca. $0.5 \mathrm{~mol}-\%$ ) without solvent. The reaction mixture was warmed to $70{ }^{\circ} \mathrm{C}$ without exclusion of air and monitored by TLC and/or GLC until total conversion of the starting material. EtOAc $(2 \mathrm{~mL})$ was added to the resulting mixture, followed by filtration through celite and washing with additional EtOAc $(4 \mathrm{~mL})$. The crude reaction product was purified by column chromatography (silica gel, hexane/EtOAc), except for compounds 4haa and 4iha, which were obtained in suitably pure states, to give the corresponding propargylamines 4 .

1-(1,3-Diphenylprop-2-yn-1-yl)piperidine (4aaa): ${ }^{[26]}$ Yellow solid. $R_{\mathrm{f}}$ $=0.44$ (hexane/EtOAc 9:1); m.p. $65.9-66.4{ }^{\circ} \mathrm{C} . t_{\mathrm{R}}=16.90 .{ }^{1} \mathrm{H}$ NMR (300 MHz, $\left.\mathrm{CDCl}_{3}\right): \delta=1.35-1.49\left(\mathrm{~m}, 2 \mathrm{H}, \mathrm{CH}_{2} \mathrm{CH}_{2} \mathrm{CH}_{2} \mathrm{~N}\right)$, $1.50-1.67\left(\mathrm{~m}, 4 \mathrm{H}, 2 \times \mathrm{CH}_{2} \mathrm{CH}_{2} \mathrm{~N}\right), 2.55(\mathrm{t}, J=5.4 \mathrm{~Hz}, 4 \mathrm{H}$, $\left.2 \times \mathrm{NCH}_{2}\right), 4.79(\mathrm{~s}, 1 \mathrm{H}, \mathrm{NCH}), 7.23-7.39(\mathrm{~m}, 6 \mathrm{H}, 6 \times \mathrm{ArH}), 7.48-$ $7.55(\mathrm{~m}, 2 \mathrm{H}, 2 \times \mathrm{ArH}), 7.60-7.68(\mathrm{~m}, 2 \mathrm{H}, 2 \times \mathrm{ArH}) \mathrm{ppm} .{ }^{13} \mathrm{C}$ NMR $\left(75 \mathrm{MHz}, \mathrm{CDCl}_{3}\right): \delta=24.6,26.3,50.8\left(5 \times \mathrm{CH}_{2}\right), 62.5$ $(\mathrm{NCH}), 86.2(\mathrm{CHC} \equiv \mathrm{C}), 87.9(\mathrm{CHC} \equiv \mathrm{C}), 123.5(\mathrm{ArC}), 127.6,128.2$, 128.4, 128.7, $131.9(10 \times \mathrm{ArCH}), 138.7$ (ArC) ppm. IR (neat): $\tilde{v}=$ 3060, 2934, 2923, 2114, 1596, 1487, 1447, 1299, 1273, 1200, 757, $724,693 \mathrm{~cm}^{-1}$. MS $(70 \mathrm{eV}): \mathrm{m} / \mathrm{z}(\%)=275(45)[\mathrm{M}]^{+}, 274(29), 232$ (15), 199 (27), 198 (100), 192 (48), 191 (100), 190 (13), 189 (59), 165 (19), 115 (24).

4-(1,3-Diphenylprop-2-yn-1-yl)morpholine (4aba): ${ }^{[26]}$ Yellow oil. $R_{\mathrm{f}}$ $=0.16$ (hexane/EtOAc 9:1). $t_{\mathrm{R}}=16.40 .{ }^{1} \mathrm{H} \mathrm{NMR}(400 \mathrm{MHz}$, $\left.\mathrm{CDCl}_{3}\right): \delta=2.50-2.78\left(\mathrm{~m}, 4 \mathrm{H}, 2 \times \mathrm{OCH}_{2}\right), 3.60-3.85(\mathrm{~m}, 4 \mathrm{H}$, $\left.2 \times \mathrm{NCH}_{2}\right), 4.79(\mathrm{~s}, 1 \mathrm{H}, \mathrm{NCH}), 7.24-7.41(\mathrm{~m}, 6 \mathrm{H}, 6 \times \mathrm{ArH}), 7.46-$ $7.56(\mathrm{~m}, 2 \mathrm{H}, 2 \times \mathrm{ArH}), 7.58-7.70(\mathrm{~m}, 2 \mathrm{H}, 2 \times \mathrm{ArH}) \mathrm{ppm} .{ }^{13} \mathrm{C}$ NMR $\left(100 \mathrm{MHz}, \mathrm{CDCl}_{3}\right): \delta=50.0\left(2 \times \mathrm{NCH}_{2}\right), 62.2(\mathrm{NCH}), 67.3$ $\left(2 \times \mathrm{OCH}_{2}\right), 85.2(\mathrm{CHC} \equiv C), 88.7(\mathrm{CHC} \equiv \mathrm{C}), 123.1(\mathrm{ArC}), 127.9$, 128.3, 128.5, 128.7, $131.9(10 \times \mathrm{ArCH}), 137.9$ (ArC) ppm. IR (neat): $\tilde{v}=3059,3029,2853,2820,2361,2331,1597,1489,1450$, $1284,1245,1114,754,724,690 \mathrm{~cm}^{-1}$. MS $(70 \mathrm{eV}): \mathrm{m} / \mathrm{z}(\%)=277$ (15) $[\mathrm{M}]^{+}, 200$ (21), 191 (100), 189 (25).

1-(1,3-Diphenylprop-2-yn-1-yl)-4-methylpiperidine (4aca): ${ }^{[27]}$ Yellow oil. $R_{\mathrm{f}}=0.78$ (hexane/EtOAc 8:2). $t_{\mathrm{R}}=17.42 .{ }^{1} \mathrm{H} \mathrm{NMR}(300 \mathrm{MHz}$, $\left.\mathrm{CDCl}_{3}\right): \delta=0.89\left(\mathrm{~d}, J=6 \mathrm{~Hz}, 3 \mathrm{H}, \mathrm{CH}_{3}\right), 1.07-1.22(\mathrm{~m}, 1 \mathrm{H}$, $\left.\mathrm{CHCH}_{3}\right), 1.29-1.45,1.49-1.74\left(2 \times \mathrm{m}, 4 \mathrm{H}, 2 \times \mathrm{CH}_{2} \mathrm{CH}_{2} \mathrm{~N}\right), 2.18$ $(\mathrm{td}, J=11.7,2.7 \mathrm{~Hz}, 1 \mathrm{H}, \mathrm{NCHH}), 2.50(\mathrm{td}, J=11.1,2.7 \mathrm{~Hz}, 1$ $\mathrm{H}, \mathrm{NCH} H), 2.59-2.72(\mathrm{~m}, 1 \mathrm{H}, \mathrm{NCH}), 2.88-3.01(\mathrm{~m}, 1 \mathrm{H}$, $\mathrm{NCH} H), 4.81$ (s, $1 \mathrm{H}, \mathrm{NCH}), 7.24-7.42$ (m, $6 \mathrm{H}, 6 \times \mathrm{ArH}), 7.47-$ $7.55(\mathrm{~m}, 2 \mathrm{H}, 2 \times \mathrm{ArH}), 7.59-7.68(\mathrm{~m}, 2 \mathrm{H}, 2 \times \mathrm{ArH}) \mathrm{ppm} .{ }^{13} \mathrm{C}$ NMR $\left(75 \mathrm{MHz}, \mathrm{CDCl}_{3}\right): \delta=22.1\left(\mathrm{CH}_{3}\right), 30.9\left(\mathrm{CHCH}_{3}\right), 34.5$, 34.9, 47.6, $52.8\left(4 \times \mathrm{CH}_{2}\right), 62.2(\mathrm{NCH}), 86.2(\mathrm{CHC} \equiv C), 87.9$ $(\mathrm{CHC} \equiv \mathrm{C}), \quad 123.5 \quad(\mathrm{ArC}), \quad 127.6, \quad 128.2, \quad 128.4, \quad 128.6,131.9$ $(10 \times \mathrm{ArCH}), 138.8(\mathrm{ArC}) \mathrm{ppm} . \mathrm{IR}($ neat $): \tilde{v}=3059,3029,2947$, 2920, 1489, 1449, 1321, 1273, 754, 722, $690 \mathrm{~cm}^{-1}$. MS (70 eV): $\mathrm{m} / \mathrm{z}$ $(\%)=289(22)[\mathrm{M}]^{+}, 288(16), 213(14), 212(80), 192(32), 191$ (100), 189 (24), 115 (10).

1-(1,3-Diphenylprop-2-yn-1-yl)-2-methylpiperidine (4ada): ${ }^{[28]}$ Diastereoisomer mixture (5.9:1). Brown oil. $R_{\mathrm{f}}=0.45,0.55$ (hexane/ EtOAc 9:1).

Major diastereoisomer: $t_{\mathrm{R}}=16.98 .{ }^{1} \mathrm{H} \mathrm{NMR}\left(300 \mathrm{MHz}, \mathrm{CDCl}_{3}\right): \delta$ $=1.18-1.28\left(\mathrm{~d}, J=6.0 \mathrm{~Hz}, 3 \mathrm{H}, \mathrm{CH}_{3} \mathrm{CH}\right), 1.30-1.54,1.57-1.79$ $\left(2 \times \mathrm{m}, 6 \mathrm{H}, \mathrm{CH}_{2} \mathrm{CH}_{2} \mathrm{CH}_{2} \mathrm{CH}\right), 2.14-2.37,2.41-2.51(2 \times \mathrm{m}, 2 \mathrm{H}$, $\left.\mathrm{NCH}_{2}\right), 2.53-2.75\left(\mathrm{~m}, 1 \mathrm{H}, \mathrm{CHCH}_{3}\right), 5.31(\mathrm{~s}, 1 \mathrm{H}, \mathrm{NCH}), 7.20$ 7.40, 7.44-7.57, 7.58-7.74 (3× m, $10 \mathrm{H}, 10 \times \mathrm{ArH}) \mathrm{ppm} .{ }^{13} \mathrm{C} \mathrm{NMR}$ $\left(75 \mathrm{MHz}, \mathrm{CDCl}_{3}\right): \delta=20.9\left(\mathrm{CH}_{3}\right), 25.2,26.4,35.7\left(3 \times \mathrm{CH}_{2}\right), 47.0$ $\left(\mathrm{NCH}_{2}\right), \quad 55.3(\mathrm{NCH}), \quad 56.2\left(\mathrm{CHCH}_{3}\right), 85.1 \quad(\mathrm{CHC} \equiv \mathrm{C}), 88.3$ $(\mathrm{CHC} \equiv \mathrm{C}), 123.6,139.8(2 \times \mathrm{ArC}), 127.3,128.0,128.2,128.3$, $128.4,128.6,131.9,132.0(10 \times \mathrm{ArCH}) \mathrm{ppm}$. IR (neat): $\tilde{v}=3055$, $3025,2929,1598,1489,1448,754,722,690 \mathrm{~cm}^{-1}$. MS $(70 \mathrm{eV}): \mathrm{m} / z$ $(\%)=289(18)[\mathrm{M}]^{+}, 275$ (33), 274 (100), 212 (46), 192 (76), 191 (100), 190 (14), 189 (56), 165 (19), 115 (11).

Selected data for the minor diastereoisomer: $t_{\mathrm{R}}=17.18 .{ }^{1} \mathrm{H} \mathrm{NMR}$ $\left(300 \mathrm{MHz}, \mathrm{CDCl}_{3}\right): \delta=1.07-1.15\left(\mathrm{~d}, J=6.3 \mathrm{~Hz}, 3 \mathrm{H}, \mathrm{CH}_{3} \mathrm{CH}\right)$, 3.05-3.23 (m, $\left.1 \mathrm{H}, \mathrm{CHCH}_{3}\right), 5.06(\mathrm{~s}, 1 \mathrm{H}, \mathrm{NCH}) \mathrm{ppm} .{ }^{13} \mathrm{C} \mathrm{NMR}$ $\left(75 \mathrm{MHz}, \mathrm{CDCl}_{3}\right): \delta=26.7,34.9\left(2 \times \mathrm{CH}_{2}\right), 54.5(\mathrm{NCH}), 58.6$ $\left(\mathrm{CHCH}_{3}\right) \mathrm{ppm}$. MS $(70 \mathrm{eV}): \mathrm{m} / \mathrm{z}(\%)=289(5)[\mathrm{M}]^{+}, 274(41), 212$ (18), 192 (26), 191 (100), 189 (20).

$N$-Benzyl- $N$-methyl-1,3-diphenylprop-2-yn-1-amine (4aea): ${ }^{[27]}$ Yellow oil. $R_{\mathrm{f}}=0.64$ (hexane/EtOAc 9:1). $t_{\mathrm{R}}=17.82 .{ }^{1} \mathrm{H} \mathrm{NMR}$ $\left(400 \mathrm{MHz}, \mathrm{CDCl}_{3}\right): \delta=2.24\left(\mathrm{~s}, 3 \mathrm{H}, \mathrm{CH}_{3}\right), 3.68$ (AB system, $J=$ $\left.13.2 \mathrm{~Hz}, 2 \mathrm{H}, \mathrm{CH}_{2}\right), 4.92(\mathrm{~s}, 1 \mathrm{H}, \mathrm{NCH}), 7.22-7.44(\mathrm{~m}, 11 \mathrm{H}$, $11 \times \mathrm{ArH}), 7.53-7.61(\mathrm{~m}, 2 \mathrm{H}, 2 \times \mathrm{ArH}), 7.65-7.71(\mathrm{~m}, 2 \mathrm{H}$, $2 \times \mathrm{ArH}) \mathrm{ppm} .{ }^{13} \mathrm{C} \mathrm{NMR}\left(100 \mathrm{MHz}, \mathrm{CDCl}_{3}\right): \delta=38.2\left(\mathrm{CH}_{3}\right), 59.1$ $\left(\mathrm{CH}_{2}\right), 59.7(\mathrm{NCH}), 84.9(\mathrm{CHC} \equiv C), 88.8(\mathrm{CHC} \equiv \mathrm{C}), 123.4(\mathrm{ArC})$, $127.2,127.6,128.3,128.5,129.2,132.0(15 \times \mathrm{ArCH}), 139.2,139.5$ $(2 \times$ ArC) ppm. IR (neat): $\tilde{v}=3060,3028,2842,2791,1598,1489$, $1450,1326,1274,1017,754,734,690 \mathrm{~cm}^{-1}$. MS $(70 \mathrm{eV}): \mathrm{m} / \mathrm{z}(\%)=$ $311(14)[\mathrm{M}]^{+}, 234$ (41), 220 (13), 192 (22), 191 (100), 189 (21), 91 (25).

1-[3-(4-Methoxyphenyl)-1-phenylprop-2-yn-1-yl]piperidine (4aab): ${ }^{[26]}$ Yellow oil. $R_{\mathrm{f}}=0.42$ (hexane/EtOAc 9:1). $t_{\mathrm{R}}=17.93 .{ }^{1} \mathrm{H}$ NMR (300 MHz, $\left.\mathrm{CDCl}_{3}\right): \delta=1.37-1.48\left(\mathrm{~m}, 2 \mathrm{H}, \mathrm{CH}_{2} \mathrm{CH}_{2} \mathrm{CH}_{2} \mathrm{~N}\right), 1.51-$ $1.69\left(\mathrm{~m}, 4 \mathrm{H}, 2 \times \mathrm{CH}_{2} \mathrm{CH}_{2} \mathrm{~N}\right), 2.55\left(\mathrm{t}, J=5.3 \mathrm{~Hz}, 4 \mathrm{H}, 2 \times \mathrm{NCH}_{2}\right)$, $3.81\left(\mathrm{~s}, 3 \mathrm{H}, \mathrm{CH}_{3}\right), 4.77(\mathrm{~s}, 1 \mathrm{H}, \mathrm{NCH}), 6.81-6.91(\mathrm{~m}, 2 \mathrm{H}$, $2 \times \mathrm{ArH}), 7.22-7.38(\mathrm{~m}, 3 \mathrm{H}, 3 \times \mathrm{ArH}), 7.42-7.49(\mathrm{~m}, 2 \mathrm{H}$, $2 \times \mathrm{ArH}), 7.60-7.66(\mathrm{~m}, 2 \mathrm{H}, 2 \times \mathrm{ArH}) \mathrm{ppm} .{ }^{13} \mathrm{C} \mathrm{NMR}(75 \mathrm{MHz}$, $\left.\mathrm{CDCl}_{3}\right): \delta=24.6,26.3,50.8\left(5 \times \mathrm{CH}_{2}\right), 55.5\left(\mathrm{OCH}_{3}\right), 62.6(\mathrm{NCH})$, $84.7(\mathrm{CHC} \equiv C), 87.7(\mathrm{CHC} \equiv \mathrm{C}), 114.0,127.5,128.1,128.7,133.3$ $(9 \times \mathrm{ArCH}), 115.6,138.9,159.5(3 \times \mathrm{ArC}) \mathrm{ppm}$. IR (neat): $\tilde{\mathrm{v}}=$ 3059, 3028, 2932, 2218, 1604, 1508, 1491, 1450, 1289, 1271, 1244, $830,805,740,699 \mathrm{~cm}^{-1}$. MS $(70 \mathrm{eV}): \mathrm{m} / z(\%)=305(23)[\mathrm{M}]^{+}, 304$ (13), 228 (38), 222 (38), 221 (100), 207 (15), 179 (10), 178 (28).

1-\{1-Phenyl-3-[4-(trifluoromethyl)phenyl]prop-2-yn-1-yl\}piperidine (4aac): Yellow oil. $R_{\mathrm{f}}=0.54$ (hexane/EtOAc 9:1). $t_{\mathrm{R}}=16.68 .{ }^{1} \mathrm{H}$ NMR (300 MHz, $\left.\mathrm{CDCl}_{3}\right): \delta=1.38-1.51\left(\mathrm{~m}, 2 \mathrm{H}, \mathrm{CH}_{2} \mathrm{CH}_{2} \mathrm{CH}_{2} \mathrm{~N}\right)$, 1.51-1.68 (m, $\left.4 \mathrm{H}, 2 \times \mathrm{CH}_{2} \mathrm{CH}_{2} \mathrm{~N}\right), 2.55(\mathrm{t}, J=5.3 \mathrm{~Hz}, 4 \mathrm{H}$, $\left.2 \times \mathrm{NCH}_{2}\right), 4.80(\mathrm{~s}, 1 \mathrm{H}, \mathrm{NCH}), 7.26-7.41$ (m, $\left.3 \mathrm{H}, 3 \times \mathrm{ArH}\right), 7.55-$ $7.65(\mathrm{~m}, 6 \mathrm{H}, 6 \times \mathrm{ArH}) \mathrm{ppm} .{ }^{13} \mathrm{C} \mathrm{NMR}\left(75 \mathrm{MHz}, \mathrm{CDCl}_{3}\right): \delta=$ 24.6, 26.3, $50.9\left(5 \times \mathrm{CH}_{2}\right), 62.5(\mathrm{NCH}), 86.7(\mathrm{CHC} \equiv C), 89.1$ $(\mathrm{CHC} \equiv \mathrm{C}), 124.1\left(\mathrm{q},{ }^{1} J_{\mathrm{C}, \mathrm{F}}=1083 \mathrm{~Hz}, \mathrm{CF}_{3}\right), 125.3\left(\mathrm{q},{ }^{3} J_{\mathrm{C}, \mathrm{F}}=15\right.$; $2 \mathrm{~Hz} \times \mathrm{ArCH}), 127.3$ (ArC), 127.8, 128.3, 128.6, $132.2(7 \times \mathrm{ArCH})$, 129.9 (q, $\left.{ }^{2} J_{\mathrm{C}, \mathrm{F}}=129 \mathrm{~Hz}, \operatorname{ArC}\right), 138.3$ (ArC) ppm. IR (neat): $\tilde{v}=$ 2934, 1614, 1450, 1321, 1125, 1065, 929, 840, 807, $744 \mathrm{~cm}^{-1}$. MS $(70 \mathrm{eV}): m / z(\%)=343(24)[\mathrm{M}]^{+}, 342(15), 267(15), 266(93), 260$ (34), 259 (100), 191 (14), 189 (22). HRMS (EI): $\mathrm{m} / \mathrm{z}$ calcd. for $\mathrm{C}_{21} \mathrm{H}_{20} \mathrm{~F}_{3} \mathrm{~N}$ 343.1548; found 343.1537 .

1-(3-Cyclohexyl-1-phenylprop-2-yn-1-yl)piperidine (4aad): ${ }^{[26]}$ Yellow oil. $R_{\mathrm{f}}=0.48$ (hexane/EtOAc 9:1). $t_{\mathrm{R}}=15.63 .{ }^{1} \mathrm{H} \mathrm{NMR}(300 \mathrm{MHz}$, $\left.\mathrm{CDCl}_{3}\right): \delta=1.26-1.60\left(\mathrm{~m}, 12 \mathrm{H}, 6 \times \mathrm{CH}_{2}\right), 1.67-1.90(\mathrm{~m}, 4 \mathrm{H}$, $\left.2 \times \mathrm{CH}_{2}\right), 2.38-2.58\left(\mathrm{~m}, 5 \mathrm{H}, 2 \times \mathrm{CH}_{2}, \mathrm{CHCH}_{2}\right), 4.55(\mathrm{~d}, J=$ $1.8 \mathrm{~Hz}, 1 \mathrm{H}, \mathrm{NCH}), 7.22-7.37$ (m, 3 H, 3× ArH), 7.53-7.59 (m, 2 $\mathrm{H}, 2 \times \mathrm{ArH}) \mathrm{ppm} .{ }^{13} \mathrm{C} \mathrm{NMR}\left(75 \mathrm{MHz}, \mathrm{CDCl}_{3}\right): \delta=24.7,24.9$, 26.1, 26.3, 33.3, $50.6\left(10 \times \mathrm{CH}_{2}\right), 29.3\left(\mathrm{CHCH}_{2}\right), 62.0(\mathrm{NCH}), 76.0$ 
$(\mathrm{CHC} \equiv \mathrm{C}), 92.4(\mathrm{CHC} \equiv \mathrm{C}), 127.3,127.9,128.7(5 \times \mathrm{ArCH}), 139.5$ (ArC) ppm. IR (neat): $\tilde{v}=3060,3027,2928,2852,2237,1491$, 1448, 1297, 1268, 988, 727, $696 \mathrm{~cm}^{-1}$. MS $(70 \mathrm{eV}): \mathrm{m} / \mathrm{z}(\%)=281$ (10) $[\mathrm{M}]^{+}, 205$ (16), 204 (100), 141 (12), 115 (17), 91 (13).

1-[1-(4-Methoxyphenyl)-3-phenylprop-2-yn-1-yl]piperidine (4baa): ${ }^{[26]}$ Yellow oil. $R_{\mathrm{f}}=0.35$ (hexane/EtOAc 8:2). $t_{\mathrm{R}}=18.20 .{ }^{1} \mathrm{H}$ NMR $\left(400 \mathrm{MHz}, \mathrm{CDCl}_{3}\right): \delta=1.38-1.49\left(\mathrm{~m}, 2 \mathrm{H}, \mathrm{CH}_{2} \mathrm{CH}_{2} \mathrm{CH}_{2} \mathrm{~N}\right), 1.51-$ $1.67\left(\mathrm{~m}, 4 \mathrm{H}, 2 \times \mathrm{CH}_{2} \mathrm{CH}_{2} \mathrm{~N}\right), 2.46-2.63\left(\mathrm{~m}, 4 \mathrm{H}, 2 \times \mathrm{NCH}_{2}\right), 3.81$ (s, $\left.3 \mathrm{H}, \mathrm{OCH}_{3}\right), 4.73(\mathrm{~s}, 1 \mathrm{H}, \mathrm{NCH}), 6.85-6.93(\mathrm{~m}, 2 \mathrm{H}, 2 \times \mathrm{ArH})$, 7.28-7.37 (m, $3 \mathrm{H}, 3 \times \mathrm{ArH}), 7.47-7.58(\mathrm{~m}, 4 \mathrm{H}, 4 \times \mathrm{ArH}) \mathrm{ppm}$. ${ }^{13} \mathrm{C} \mathrm{NMR}\left(100 \mathrm{MHz}, \mathrm{CDCl}_{3}\right): \delta=24.6,26.3,50.7\left(5 \times \mathrm{CH}_{2}\right), 55.4$ $\left(\mathrm{OCH}_{3}\right), 61.9(\mathrm{NCH}), 86.6(\mathrm{CHC} \equiv C), 87.7(\mathrm{CHC} \equiv \mathrm{C}), 113.5$, $128.1,128.4,129.7(9 \times \mathrm{ArCH}), 123.5,130.8(2 \times \mathrm{ArC}), 131.9$ $(\mathrm{ArCH}), 159.1\left(\mathrm{ArCOCH}_{3}\right) \mathrm{ppm}$. IR (neat): $\tilde{v}=3054,2931,1609$, 1584, 1508, 1488, 1441, 1272, 1244, 1168, 1035, 754, $690 \mathrm{~cm}^{-1}$. MS $(70 \mathrm{eV}): m / z(\%)=305(16)[\mathrm{M}]^{+}, 222(23), 221(100), 178(15)$.

1-[1-(2-Iodophenyl)-3-phenylprop-2-yn-1-yl|piperidine (4caa): Yellow oil. $R_{\mathrm{f}}=0.79$ (hexane/EtOAc 7:3). $t_{\mathrm{R}}=18.48 .{ }^{1} \mathrm{H} \mathrm{NMR}(400 \mathrm{MHz}$, $\left.\mathrm{CDCl}_{3}\right): \delta=1.39-1.62\left[\mathrm{~m}, 6 \mathrm{H},\left(\mathrm{CH}_{2}\right)_{3} \mathrm{CH}_{2} \mathrm{~N}\right], 2.44-2.72(\mathrm{~m}, 4 \mathrm{H}$, $\left.2 \times \mathrm{NCH}_{2}\right), 4.83(\mathrm{~s}, 1 \mathrm{H}, \mathrm{NCH}), 7.26(\mathrm{~s}, 1 \mathrm{H}, \mathrm{ArH}), 7.29-7.38(\mathrm{~m}$, $4 \mathrm{H}, 4 \times \mathrm{ArH}), 7.47-7.54(\mathrm{~m}, 2 \mathrm{H}, 2 \times \mathrm{ArH}), 7.70-7.75(\mathrm{dd}, J=$ $10.8,1.6 \mathrm{~Hz}, 1 \mathrm{H}, \mathrm{ArH}), 7.85-7.92(\mathrm{dd}, J=10.4,2.4 \mathrm{~Hz}, 1 \mathrm{H}$, ArH) ppm. ${ }^{13} \mathrm{C} \mathrm{NMR}\left(100 \mathrm{MHz}, \mathrm{CDCl}_{3}\right): \delta=24.7,26.2,60.6$ $\left(5 \times \mathrm{CH}_{2}\right), 65.9(\mathrm{NCH}), 85.6(\mathrm{CHC} \equiv C), 88.8(\mathrm{CHC} \equiv \mathrm{C}), 101.6$ (CI), 123.3 (ArC), 127.6, 128.3, 128.4, 129.3, 130.3, 131.9, 140.2 $(9 \times \mathrm{ArCH}), 140.9$ (ArC) ppm. IR (neat): $\tilde{v}=3055,2930,1562$, 1488, 1461, 1451, 1434, 1298, 1266, 1203, 753, 742, $689 \mathrm{~cm}^{-1}$. MS $(70 \mathrm{eV}): m / z(\%)=401(30)[\mathrm{M}]^{+}, 400(24), 318(42), 317(61), 274$ (13), 199 (16), 198 (100), 191 (43), 190 (23), 189 (88), 188 (12), 187 (10), 165 (12), 115 (11). HRMS (EI): $\mathrm{m} / z$ calcd. for $\mathrm{C}_{20} \mathrm{H}_{20} \mathrm{IN}$ 401.0640; found 401.0610.

1-[1-(3-Nitrophenyl)-3-phenylprop-2-yn-1-yl]piperidine $\quad$ (4daa): ${ }^{[29]}$ Yellow oil. $R_{\mathrm{f}}=0.27$ (hexane/EtOAc 9:1). $t_{\mathrm{R}}=20.15 .{ }^{1} \mathrm{H}$ NMR $\left(400 \mathrm{MHz}, \mathrm{CDCl}_{3}\right): \delta=1.38-1.49\left(\mathrm{~m}, 2 \mathrm{H}, \mathrm{CH}_{2} \mathrm{CH}_{2} \mathrm{CH}_{2} \mathrm{~N}\right), 1.52$ $1.70\left(\mathrm{~m}, 4 \mathrm{H}, 2 \times \mathrm{CH}_{2} \mathrm{CH}_{2} \mathrm{~N}\right), 2.35-2.73\left(\mathrm{~m}, 4 \mathrm{H}, 2 \times \mathrm{NCH}_{2}\right), 4.87$ (s, 1 H, NCH), 7.30-7.42, 7.47-7.61 (2× m, 6 H, 6× ArCH), 8.01 (d, $J=7.7 \mathrm{~Hz}, 1 \mathrm{H}, \mathrm{ArCH}), 8.15(\mathrm{~d}, J=7.7 \mathrm{~Hz}, 1 \mathrm{H}, \mathrm{ArCH}), 8.55$ (s, $1 \mathrm{H}, \mathrm{ArCH}) \mathrm{ppm} .{ }^{13} \mathrm{C} \mathrm{NMR}\left(100 \mathrm{MHz}, \mathrm{CDCl}_{3}\right): \delta=24.4,26.3$, $50.8\left(5 \times \mathrm{CH}_{2}\right), 61.8(\mathrm{NCH}), 84.3(\mathrm{CHC} \equiv C), 89.2(\mathrm{CHC} \equiv \mathrm{C})$, $122.7,123.5,128.5,128.6,129.1,132.0,134.6(9 \times \mathrm{ArCH}), 122.8$, 141.5, $148.4(3 \times \operatorname{ArC}) \mathrm{ppm}$. IR (neat): $\tilde{v}=3074,2934,2848,2808$, $1736,1528,1346,1091,754,727,690 \mathrm{~cm}^{-1}$. MS $(70 \mathrm{eV}): \mathrm{m} / z(\%)=$ 320 (20) [M] $]^{+}, 319$ (12), 277 (10), 236 (45), 199 (18), 198 (100), 190 (26), 189 (48), 115 (13).

1-[1-(Naphthalen-2-yl)-3-phenylprop-2-yn-1-yl]piperidine (4eaa): ${ }^{[26]}$ Beige solid. $R_{\mathrm{f}}=0.50$ (hexane/EtOAc 9:1); m.p. 126.4-127.9 ${ }^{\circ} \mathrm{C}$. $t_{\mathrm{R}}=21.44 .{ }^{1} \mathrm{H}$ NMR $\left(300 \mathrm{MHz}, \mathrm{CDCl}_{3}\right): \delta=1.36-1.50(\mathrm{~m}, 2 \mathrm{H}$, $\mathrm{CH}_{2} \mathrm{CH}_{2} \mathrm{CH}_{2} \mathrm{~N}$ ), 1.52-1.71 (m, $\left.4 \mathrm{H}, 2 \times \mathrm{CH}_{2} \mathrm{CH}_{2} \mathrm{~N}\right), 2.60(\mathrm{~s}, 4 \mathrm{H}$, $\left.2 \times \mathrm{NCH}_{2}\right), 4.94(\mathrm{~s}, 1 \mathrm{H}, \mathrm{NCH}), 7.32-7.40(\mathrm{~m}, 3 \mathrm{H}, 3 \times \mathrm{ArH}), 7.44$ $7.52(\mathrm{~m}, 2 \mathrm{H}, 2 \times \mathrm{ArH}), 7.53-7.61(\mathrm{~m}, 2 \mathrm{H}, 2 \times \mathrm{ArH}), 7.73-7.79$ $(\mathrm{m}, 1 \mathrm{H}, \mathrm{ArH}), 7.80-7.92(\mathrm{~m}, 3 \mathrm{H}, 3 \times \mathrm{ArH}), 8.08(\mathrm{~s}, 1 \mathrm{H}$, ArH) ppm. ${ }^{13} \mathrm{C}$ NMR $\left(75 \mathrm{MHz}, \mathrm{CDCl}_{3}\right): \delta=24.6,26.3,60.0$ $\left(5 \times \mathrm{CH}_{2}\right), 62.7(\mathrm{NCH}), 86.2(\mathrm{CHC} \equiv \mathrm{C}), 88.2(\mathrm{CHC} \equiv \mathrm{C}), 123.5$ (ArC), 126.0, 126.1, 126.8, 127.4, 127.7, 127.9, 128.2, 128.5, 132.0 $(12 \times \mathrm{ArCH}), 133.1,133.2,136.4(3 \times \mathrm{ArC}) \mathrm{ppm}$. IR (neat): $\tilde{v}=$ 3055, 2934, 2356, 1596, 1507, 1488, 1445, 1435, 1266, 784, 762, 695. MS $(70 \mathrm{eV}): \mathrm{m} / z(\%)=325(14)[\mathrm{M}]^{+}, 242(47), 241(100), 240$ (12), 239 (33), 198 (18).

1-[1-(Benzofuran-2-yl)-3-phenylprop-2-yn-1-yl|piperidine (4faa): Yellow solid. $R_{\mathrm{f}}=0.48$ (hexane/EtOAc 9:1); m.p. 93.5-96.9 ${ }^{\circ} \mathrm{C} . t_{\mathrm{R}}=$ 20.13. ${ }^{1} \mathrm{H}$ NMR $\left(300 \mathrm{MHz}, \mathrm{CDCl}_{3}\right): \delta=1.38-1.52(\mathrm{~m}, 2 \mathrm{H}$, $\left.\mathrm{CH}_{2} \mathrm{CH}_{2} \mathrm{CH}_{2} \mathrm{~N}\right), 1.53-1.79\left(\mathrm{~m}, 4 \mathrm{H}, 2 \times \mathrm{CH}_{2} \mathrm{CH}_{2} \mathrm{~N}\right), 2.66(\mathrm{t}, J=$ $\left.5.3 \mathrm{~Hz}, 4 \mathrm{H}, 2 \times \mathrm{NCH}_{2}\right), 5.01(\mathrm{~d}, J=0.9 \mathrm{~Hz}, 1 \mathrm{H}, \mathrm{NCH}), 6.91(\mathrm{t}$, $J=0.9 \mathrm{~Hz}, 1 \mathrm{H}, \mathrm{ArH}), 7.18-7.38(\mathrm{~m}, 5 \mathrm{H}, 5 \times \mathrm{ArH}), 7.49-7.60(\mathrm{~m}$, $4 \mathrm{H}, 4 \times \mathrm{ArH}) \mathrm{ppm} .{ }^{13} \mathrm{C} \mathrm{NMR}\left(75 \mathrm{MHz}, \mathrm{CDCl}_{3}\right): \delta=24.4,26.1$, $50.8\left(5 \times \mathrm{CH}_{2}\right), 57.2(\mathrm{NCH}), 83.5(\mathrm{CHC} \equiv \mathrm{C}), 87.1(\mathrm{CHC} \equiv \mathrm{C})$, $106.5,111.7,121.0,122.9,124.3,128.4,128.5,132.0(10 \times \mathrm{ArCH})$, 128.1, 154.7, $155.4(4 \times \operatorname{ArC}) \mathrm{ppm}$. IR (neat): $\tilde{v}=2936,2799,2094$, $1313,1295,1255,985,762,753,743,695 \mathrm{~cm}^{-1}$. MS $(70 \mathrm{eV}): \mathrm{m} / \mathrm{z}$ $(\%)=315$ (15) [M] $]^{+}, 232$ (32), 231 (100), 202 (17), 102 (10). HRMS (EI): $m / z$ calcd. for $\mathrm{C}_{22} \mathrm{H}_{21} \mathrm{NO} 315.1623$; found 315.1660 .

1-(1-Phenyldodec-1-yn-3-yl)piperidine (4gaa): Yellow oil. $R_{\mathrm{f}}=0.44$ (hexane/EtOAc 8:2). $t_{\mathrm{R}}=16.90 .{ }^{1} \mathrm{H}$ NMR $\left(400 \mathrm{MHz}, \mathrm{CDCl}_{3}\right): \delta=$ $0.88\left(\mathrm{t}, J=6.8 \mathrm{~Hz}, 3 \mathrm{H}, \mathrm{CH}_{3}\right), 1.23-1.77\left(\mathrm{~m}, 22 \mathrm{H}, 11 \times \mathrm{CH}_{2}\right)$, 2.43-2.56, 2.63-2.77 (2× m, $\left.4 \mathrm{H}, 2 \times \mathrm{NCH}_{2}\right), 3.41-3.55(\mathrm{~m}, 1 \mathrm{H}$, $\mathrm{NCH}), \quad 7.26-7.32(\mathrm{~m}, 3 \mathrm{H}, 3 \times \mathrm{ArH}), 7.40-7.48(\mathrm{~m}, 2 \mathrm{H}$, $2 \times \mathrm{ArH}) \mathrm{ppm} .{ }^{13} \mathrm{C} \mathrm{NMR}\left(100 \mathrm{MHz}, \mathrm{CDCl}_{3}\right): \delta=14.3\left(\mathrm{CH}_{3}\right), 22.8$, 24.7, 26.4, 27.1, 29.5, 29.6, 29.7, 32.1, $33.6\left(13 \times \mathrm{CH}_{2}\right), 58.8(\mathrm{NCH})$, $85.7(\mathrm{CHC} \equiv C), 88.4(\mathrm{CHC} \equiv \mathrm{C}), 123.8(\mathrm{ArC}), 127.9,128.3,131.9$ $(5 \times \mathrm{ArCH}) \mathrm{ppm} . \mathrm{IR}$ (neat): $\tilde{v}=3064,3025,2924,2853,1488,1465$, 1098, 754, $689 \mathrm{~cm}^{-1}$. MS (70 eV): $\mathrm{m} / z(\%)=325(0.15)[\mathrm{M}]^{+}, 199$ (15), 198 (100), 115 (11). HRMS (EI): $\mathrm{m} / z$ calcd. for $\mathrm{C}_{23} \mathrm{H}_{35} \mathrm{~N}$ 325.2770 ; found 325.2731

1-(1-Cyclohexyl-3-phenylprop-2-yn-1-yl)piperidine (4haa): ${ }^{[26]}$ Brown oil. $R_{\mathrm{f}}=0.48$ (hexane). $t_{\mathrm{R}}=16.26 .{ }^{1} \mathrm{H}$ NMR $\left(400 \mathrm{MHz}, \mathrm{CDCl}_{3}\right): \delta$ $=0.87-1.09\left(\mathrm{~m}, 2 \mathrm{H}, \mathrm{CH}_{2}\right), 1.13-1.81\left(\mathrm{~m}, 13 \mathrm{H}, 5 \times \mathrm{CH}_{2}, 2 \times \mathrm{CHH}\right.$, $\left.\mathrm{CHCH}_{2}\right), 2.03,2.10(2 \times \mathrm{d}, J=13.2,11.2 \mathrm{~Hz}, 2 \mathrm{H}, 2 \times \mathrm{CHH}), 2.35$ 2.45, 2.57-2.68 (2× m, $\left.4 \mathrm{H}, 2 \times \mathrm{NCH}_{2}\right), 3.10(\mathrm{~d}, J=9.6 \mathrm{~Hz}, 1 \mathrm{H}$, $\mathrm{NCH}), \quad 7.21-7.32(\mathrm{~m}, 3 \mathrm{H}, 3 \times \mathrm{ArH}), 7.39-7.48(\mathrm{~m}, 2 \mathrm{H}$, $2 \times \mathrm{ArH}) \mathrm{ppm} .{ }^{13} \mathrm{C} \mathrm{NMR}\left(100 \mathrm{MHz}, \mathrm{CDCl}_{3}\right): \delta=24.9,26.2,26.4$, 26.9, 30.6, $31.5\left(8 \times \mathrm{CH}_{2}\right), 39.7\left(\mathrm{CHCH}_{2}\right), 50.9\left(2 \times \mathrm{NCH}_{2}\right), 64.5$ $(\mathrm{NCH}), 86.3(\mathrm{CHC} \equiv \mathrm{C}), 87.9(\mathrm{CHC} \equiv \mathrm{C}), 123.9,127.7,128.3,131.8$ $(5 \times \mathrm{ArCH}) \mathrm{ppm}$. IR (neat): $\tilde{v}=3054,3025,2926,2849,1597,1488$, $1443,1102,996,753,689 \mathrm{~cm}^{-1}$. MS $(70 \mathrm{eV}): \mathrm{m} / z(\%)=281(0.08)$ $[\mathrm{M}]^{+}, 199$ (16), 198 (100), 115 (18).

$N$-(1-Cyclohexyl-3-phenylprop-2-yn-1-yl)- $N$-methylaniline $(4 \mathbf{h f a})$ : $^{[30]}$ Yellow oil. $R_{\mathrm{f}}=0.85$ (hexane/EtOAc 8:2). $t_{\mathrm{R}}=17.98 .{ }^{1} \mathrm{H} \mathrm{NMR}$ $\left(400 \mathrm{MHz}, \mathrm{CDCl}_{3}\right): \delta=1.06-1.34\left(\mathrm{~m}, 4 \mathrm{H}, 2 \times \mathrm{CH}_{2}\right), 1.65-1.93(\mathrm{~m}$, $\left.6 \mathrm{H}, 3 \times \mathrm{CH}_{2}\right), 2.16-2.18\left(\mathrm{~m}, 1 \mathrm{H}, \mathrm{CHCH}_{2}\right), 2.91\left(\mathrm{~s}, 3 \mathrm{H}, \mathrm{CH}_{3}\right)$, $4.34(\mathrm{~d}, J=12.8 \mathrm{~Hz}, 1 \mathrm{H}, \mathrm{NCH}), 6.72-6.79$ (m, $1 \mathrm{H}, \mathrm{ArH}), 6.84$ $6.92(\mathrm{~m}, 2 \mathrm{H}, 2 \times \mathrm{ArH}), 7.23-7.30(\mathrm{~m}, 5 \mathrm{H}, 5 \times \mathrm{ArH}), 7.36-7.43$ (m, $2 \mathrm{H}, 2 \times \mathrm{ArH}) \mathrm{ppm} .{ }^{13} \mathrm{C} \mathrm{NMR}\left(100 \mathrm{MHz}, \mathrm{CDCl}_{3}\right): \delta=26.1$, 26.3, 26.6, 30.3, $30.8\left(5 \times \mathrm{CH}_{2}\right), 33.6\left(\mathrm{CHCH}_{2}\right), 41.5\left(\mathrm{CH}_{3}\right), 58.9$ $(\mathrm{NCH}), 85.4(\mathrm{CHC} \equiv \mathrm{C}), 87.6(\mathrm{CHC} \equiv \mathrm{C}), 111.8,114.4,117.7,128.0$, $128.3,129.2,131.8(10 \times \mathrm{ArCH}), 123.5,150.7(2 \times \mathrm{ArC}) \mathrm{ppm} . \mathrm{IR}$ (neat): $\tilde{v}=3058,3030,2850,1596,1502,1489,1275,750,689 \mathrm{~cm}^{-1}$. $\operatorname{MS}(70 \mathrm{eV}): m / z(\%)=303(6)[\mathrm{M}]^{+}, 301(12), 290(13), 280(11)$, 221 (18), 220 (100), 218 (13), 208 (14), 207 (56), 204 (20), 191 (11), 179 (11), 177 (16), 167 (16), 165 (14), 152 (12), 141 (12), 115 (20), 107 (22), 106 (28), 105 (32), 104 (25), 103 (10), 102 (11), 91 (17), 79 (15), 78 (20), 77 (50), 75 (14), 67 (13), 55 (11), 54 (11), 51 (21).

1-Cyclohexyl- $N$-methyl-3-phenyl- $N$-(1-phenylethyl)prop-2-yn-1amine (4hga): Diastereoisomer mixture (1:0.80). Yellow solid. $R_{\mathrm{f}}=$ 0.85 (hexane/EtOAc 8:2); m.p. 83.8-86.4 ${ }^{\circ}$ C. $t_{\mathrm{R}}=17.96$ and 18.15 . ${ }^{1} \mathrm{H}$ NMR $\left(300 \mathrm{MHz}, \mathrm{CDCl}_{3}\right): \delta=0.59-1.30,1.38-1.88,1.91-2.03$ $\left(3 \times \mathrm{m}, \quad 20 \mathrm{H}, \quad 10 \times \mathrm{CH}_{2}\right), 1.33-1.37(\mathrm{~d}, J=6.6 \mathrm{~Hz}, 6 \mathrm{H}$, $\left.2 \times \mathrm{CH}_{3} \mathrm{CH}\right), 2.05,2.31\left(2 \times \mathrm{s}, 6 \mathrm{H}, 2 \times \mathrm{NCH}_{3}\right), 2.09-2.25(\mathrm{~m}, 2 \mathrm{H}$, $\left.2 \times \mathrm{CHCH}_{2}\right), 3.07,3.59(2 \times \mathrm{d}, J=10.2 \mathrm{~Hz}, 2 \mathrm{H}, 2 \times \mathrm{NCH}), 3.61$, $3.69\left(2 \times \mathrm{q}, J=6.6 \mathrm{~Hz}, 2 \mathrm{H}, 2 \times \mathrm{CHCH}_{3}\right), 7.15-7.52(\mathrm{~m}, 20 \mathrm{H}$, $20 \times \mathrm{ArH}) \mathrm{ppm} .{ }^{13} \mathrm{C} \mathrm{NMR}\left(75 \mathrm{MHz}, \mathrm{CDCl}_{3}\right): \delta=21.5,22.1$ $\left(2 \times \mathrm{CH}_{3} \mathrm{CH}\right), 26.1,26.2,26.4 .26 .8,30.3,31.4,31.6\left(10 \times \mathrm{CH}_{2}\right)$, $\begin{array}{llllll}33.0, & 35.0 & \left(2 \times \mathrm{CHCH}_{2}\right), & 40.2, & 40.4 & \left(2 \times \mathrm{NCH}_{3}\right), \quad 57.8, \quad 60.0\end{array}$ $(2 \times \mathrm{NCH}), 63.1,63.2\left(2 \times \mathrm{CHCH}_{3}\right), 86.3,86.5(2 \times \mathrm{CHC} \equiv C)$, $87.6,87.9(2 \times \mathrm{CHC} \equiv \mathrm{C}), 123.9,124.0,126.7,126.9,127.5,127.7$, 


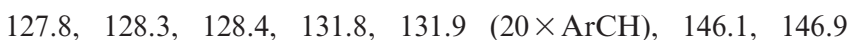
$(2 \times$ ArC) ppm. IR (neat): $\tilde{v}=3061,3027,2930,2847,2359,2342$, $1596,1488,1449,753,700,689 \mathrm{~cm}^{-1}$. MS $(70 \mathrm{eV})\left(t_{\mathrm{R}}=17.96\right): \mathrm{m} / \mathrm{z}$ $(\%)=331(0.07)[\mathrm{M}]^{+}, 249(10), 248(100), 144(58), 115(14), 105$ (52), 77 (9). MS $(70 \mathrm{eV})\left(t_{\mathrm{R}}=18.15\right): \mathrm{m} / \mathrm{z}(\%)=331(0.09)[\mathrm{M}]^{+}$, 249 (20), 248 (100), 144 (61), 115 (15), 105 (56), 77 (10). HRMS (EI): $m / z$ calcd. for $\mathrm{C}_{24} \mathrm{H}_{29} \mathrm{~N} 331.2300$; found 331.2331.

1-(1-Cyclohexylnon-2-yn-1-yl)piperidine (4hae): ${ }^{[31]}$ Yellow oil. $R_{\mathrm{f}}=$ 0.79 (hexane/EtOAc 9:1). $t_{\mathrm{R}}=15.68 .{ }^{1} \mathrm{H}$ NMR (400 MHz, $\left.\mathrm{CDCl}_{3}\right)$ : $\delta=0.89\left(\mathrm{t}, J=6.9 \mathrm{~Hz}, 3 \mathrm{H}, \mathrm{CH}_{3}\right), 1.02-1.82\left(\mathrm{~m}, 23 \mathrm{H}, 11 \times \mathrm{CH}_{2}\right.$, $\left.\mathrm{CHCH}_{2}\right), 1.88-2.08\left(\mathrm{~m}, 2 \mathrm{H}, \mathrm{CH}_{2}\right), 2.19-2.24(\mathrm{td}, J=6.9, J=$ $\left.2.1 \mathrm{~Hz}, 2 \mathrm{H}, \mathrm{C} \equiv \mathrm{CCH}_{2}\right), 2.25-2.35\left(\mathrm{~m}, 2 \mathrm{H}, \mathrm{CH}_{2}\right), 2.48-2.57$ (m, 2 $\left.\mathrm{H}, \mathrm{CH}_{2}\right), 2.84(\mathrm{dt}, J=9.7, J=1.8 \mathrm{~Hz}, 1 \mathrm{H}, \mathrm{NCH}) \mathrm{ppm} .{ }^{13} \mathrm{C} \mathrm{NMR}$ $\left(100 \mathrm{MHz}, \mathrm{CDCl}_{3}\right): \delta=14.2\left(\mathrm{CH}_{3}\right), 18.8,22.8,24.9,26.3,26.4$, 26.9, 28.7, 29.4, 30.6, 31.3, $31.5\left(13 \times \mathrm{CH}_{2}\right), 39.8\left(\mathrm{CHCH}_{2}\right), 50.7$ $\left(2 \times \mathrm{CH}_{2}\right), 64.1(\mathrm{NCH}), 77.5(\mathrm{CHC} \equiv C), 85.9(\mathrm{CHC} \equiv \mathrm{C}) \mathrm{ppm}$. IR (neat): $\tilde{V}=2924,2851,1449,1299,1261,1230,1156,1102$, $996 \mathrm{~cm}^{-1}$. MS $(70 \mathrm{eV}): \mathrm{m} / z(\%)=289(0.21)[\mathrm{M}]^{+}, 207(31), 206$ (100).

$N, N$-Diethyl-3-phenylprop-2-yn-1-amine (4iha): ${ }^{[32]}$ Yellow oil. $R_{\mathrm{f}}=$ 0.42 (hexane/EtOAc 8:2). $t_{\mathrm{R}}=16.31 .{ }^{1} \mathrm{H} \mathrm{NMR}\left(300 \mathrm{MHz}, \mathrm{CDCl}_{3}\right.$ ): $\delta=1.14\left(\mathrm{t}, J=7.2 \mathrm{~Hz}, 6 \mathrm{H}, 2 \times \mathrm{CH}_{3}\right), 2.67(\mathrm{q}, J=6.8 \mathrm{~Hz}, 4 \mathrm{H}$, $\left.2 \times \mathrm{CH}_{2} \mathrm{CH}_{3}\right), 3.68\left(\mathrm{~s}, 2 \mathrm{H}, \mathrm{CH}_{2} \mathrm{~N}\right), 7.26-7.32(\mathrm{~m}, 3 \mathrm{H}, 3 \times \mathrm{ArH})$, 7.39-7.46 (m, $2 \mathrm{H}, 2 \times \mathrm{ArH})$ ppm. ${ }^{13} \mathrm{C} \mathrm{NMR}\left(75 \mathrm{MHz}, \mathrm{CDCl}_{3}\right): \delta$ $=12.5\left(2 \times \mathrm{CH}_{3}\right), 41.4\left(2 \times \mathrm{CH}_{2} \mathrm{CH}_{3}\right), 47.4\left(\mathrm{CH}_{2} \mathrm{C} \equiv \mathrm{C}\right), 83.9$ $(\mathrm{CHC} \equiv C), 85.4(\mathrm{CHC} \equiv \mathrm{C}), 123.3,128.1,128.4(5 \times \mathrm{ArCH}), 131.8$ $($ ArC) ppm. IR (neat): $\tilde{v}=3079,3056,2969,2818,1597,1488$, 1321, 1068, 754, $690 \mathrm{~cm}^{-1}$. MS $(70 \mathrm{eV}): \mathrm{m} / \mathrm{z}(\%)=187(10)[\mathrm{M}]^{+}$, 172(49), 116 (13), 115 (100).

1-I(5S)-5,9-Dimethyl-1-phenyldec-8-en-1-yn-3-yl]piperidine (4jaa): Diastereoisomer mixture (2.5:1) separated by column chromatography.

Major diastereoisomer: Yellow oil. $R_{\mathrm{f}}=0.61$ (hexane/EtOAc 9:1). $[a]_{\mathrm{D}}^{20}=-9.1\left(c=1.0, \mathrm{CHCl}_{3}\right) \cdot t_{\mathrm{R}}=17.20 .{ }^{1} \mathrm{H} \mathrm{NMR}(400 \mathrm{MHz}$, $\left.\mathrm{CDCl}_{3}\right): \delta=0.96\left(\mathrm{~d}, J=6.4 \mathrm{~Hz}, 3 \mathrm{H}, \mathrm{CHCH}_{3}\right), 1.09-1.28(\mathrm{~m}, 1 \mathrm{H}$, $\left.\mathrm{CHCH}_{3}\right), 1.36-1.49,1.50-1.84\left(2 \times \mathrm{m}, 16 \mathrm{H}, 5 \times \mathrm{CH}_{2}, 2 \times \mathrm{CH}_{3}\right)$, 1.90-2.11 (m, $\left.2 \mathrm{H}, \mathrm{CHCH}_{2} \mathrm{CH}_{2}\right), 2.39-2.53,2.59-2.74(2 \times \mathrm{m}, 4 \mathrm{H}$, $\left.2 \times \mathrm{NCH}_{2}\right), 3.51-3.63(\mathrm{dd}, J=8.4,6.8 \mathrm{~Hz}, 1 \mathrm{H}, \mathrm{NCH}), 5.06-5.16$ $\left[\mathrm{td}, J=6.4, J=1.5 \mathrm{~Hz}, 1 \mathrm{H}, \mathrm{CHC}\left(\mathrm{CH}_{3}\right)_{2}\right], 7.22-7.33(\mathrm{~m}, 3 \mathrm{H}$, $3 \times \mathrm{ArH}), 7.38-7.46(\mathrm{~m}, 2 \mathrm{H}, 2 \times \mathrm{ArH}) \mathrm{ppm} .{ }^{13} \mathrm{C} \mathrm{NMR}(100 \mathrm{MHz}$, $\left.\mathrm{CDCl}_{3}\right): \delta=17.8,20.1,25.9\left(3 \times \mathrm{CH}_{3}\right), 24.8,25.6,26.4,36.7,40.5$, $50.7\left(8 \times \mathrm{CH}_{2}\right), 29.8\left(\mathrm{CHCH}_{3}\right), 56.4(\mathrm{NCH}), 85.6(\mathrm{CHC} \equiv \mathrm{C}), 88.6$ $(\mathrm{CHC} \equiv \mathrm{C}), 123.8 \quad(\mathrm{ArC}), 125.0 \quad(\mathrm{C}=\mathrm{CH}), 127.8,128.3,131.8$ $(5 \times \mathrm{ArCH}), 131.3(C=\mathrm{CH}) \mathrm{ppm}$. IR (neat): $\tilde{v}=2929,2852,1488$, $1452,1441,1155,1101,754,690 \mathrm{~cm}^{-1}$. MS $(70 \mathrm{eV}): \mathrm{m} / \mathrm{z}(\%)=323$ (0.29) [M] ${ }^{+}, 199$ (17), 198 (100), 138 (17), 115 (18), 102 (9). HRMS (EI): $m / z$ calcd. for $\mathrm{C}_{23} \mathrm{H}_{33} \mathrm{~N} 323.2613$; found 323.2586 .

Minor diastereoisomer: Yellow oil. $R_{\mathrm{f}}=0.45$ (hexane/EtOAc 9:1). $[a]_{\mathrm{D}}^{20}=-16.9\left(c=1.0, \mathrm{CHCl}_{3}\right) \cdot t_{\mathrm{R}}=17.16 .{ }^{1} \mathrm{H} \mathrm{NMR}(400 \mathrm{MHz}$, $\left.\mathrm{CDCl}_{3}\right): \delta=0.95\left(\mathrm{~d}, J=6.5 \mathrm{~Hz}, 3 \mathrm{H}, \mathrm{CHCH}_{3}\right), 1.18-1.31(\mathrm{~m}, 1 \mathrm{H}$, $\left.\mathrm{CHCH}_{3}\right), 1.33-1.52,1.53-1.86\left(\mathrm{~m}, 16 \mathrm{H}, 5 \times \mathrm{CH}_{2}, 2 \times \mathrm{CH}_{3}\right), 1.93-$ $2.09\left(\mathrm{~m}, 2 \mathrm{H}, \mathrm{CHCH}_{2} \mathrm{CH}_{2}\right), 2.40-2.57,2.63-2.76(2 \times \mathrm{m}, 4 \mathrm{H}$, $\left.2 \times \mathrm{NCH}_{2}\right), 3.53-3.63(\mathrm{dd}, J=10.2,4.6 \mathrm{~Hz}, 1 \mathrm{H}, \mathrm{NCH}), 5.05-5.18$ $\left[\mathrm{td}, J=6.4,1.3 \mathrm{~Hz}, 1 \mathrm{H}, \mathrm{CHC}\left(\mathrm{CH}_{3}\right)_{2}\right], 7.23-7.33(\mathrm{~m}, 3 \mathrm{H}$, $3 \times \mathrm{ArH}), 7.39-7.47$ (m, $2 \mathrm{H}, 2 \times \mathrm{ArH}) \mathrm{ppm} .{ }^{13} \mathrm{C} \mathrm{NMR}(100 \mathrm{MHz}$, $\left.\mathrm{CDCl}_{3}\right): \delta=17.8,19.4,25.8\left(3 \times \mathrm{CH}_{3}\right), 24.8,25.5,26.4,37.7,40.4$, $50.9\left(8 \times \mathrm{CH}_{2}\right), 29.9\left(\mathrm{CHCH}_{3}\right), 56.9(\mathrm{NCH}), 85.9(\mathrm{CHC} \equiv \mathrm{C}), 88.2$ $(\mathrm{CHC} \equiv \mathrm{C}), 123.8 \quad(\mathrm{ArC}), 125.0 \quad(\mathrm{C}=\mathrm{CH}), 127.9, \quad 128.3,131.8$ $(5 \times \mathrm{ArCH}), 131.3(C=\mathrm{CH}) \mathrm{ppm}$. IR (neat): $\tilde{v}=2929,2852,1488$, $1452,1441,1155,1102,754,690 \mathrm{~cm}^{-1}$. MS $(70 \mathrm{eV}): \mathrm{m} / z(\%)=323$ (0.25) [M] $]^{+}, 199$ (17), 198 (100), 138 (15), 115 (18), 102 (10). HRMS (EI): $m / z$ calcd. for $\mathrm{C}_{23} \mathrm{H}_{33} \mathrm{~N} 323.2613$; found 323.2577 .
(2R)-1-[(1R)-1,3-Diphenylprop-2-yn-1-yl]-2-(methoxymethyl)pyrrolidine (4aia): Diastereoisomer mixture (15:1). Major diastereoisomer: Pale yellow oil. $R_{\mathrm{f}}=0.24$ (hexane/EtOAc 9:1). $[\alpha]_{\mathrm{D}}^{20}=$ $+89.8\left(c=1.0, \mathrm{CHCl}_{3}\right)$ [ref. ${ }^{[17 \mathrm{a}]}-107.8\left(c 0.34, \mathrm{CHCl}_{3}\right)$, ent-4aia]. $t_{\mathrm{R}}=17.41 .{ }^{1} \mathrm{H} \mathrm{NMR}\left(300 \mathrm{MHz}, \mathrm{CDCl}_{3}\right): \delta=1.56-1.76,1.88-2.02$ $\left(2 \times \mathrm{m}, 4 \mathrm{H}, \mathrm{CH}_{2} \mathrm{CH}_{2} \mathrm{CH}\right), 2.52-2.64,2.68-2.81(2 \times \mathrm{m}, 2 \mathrm{H}$, $\left.\mathrm{NCH}_{2}\right), 3.24-3.36\left(\mathrm{~m}, 1 \mathrm{H}, \mathrm{CHCH}_{2}\right), 3.42\left(\mathrm{~s}, 3 \mathrm{H}, \mathrm{OCH}_{3}\right), 3.43-$ $3.58\left(\mathrm{~m}, 2 \mathrm{H}, \mathrm{CH}_{2} \mathrm{O}\right), 5.33(\mathrm{~s}, 1 \mathrm{H}, \mathrm{NCH}), 7.24-7.38,7.47-7.54$, 7.60-7.67 (3×m, $10 \mathrm{H}, \mathrm{ArH}) \mathrm{ppm} .{ }^{13} \mathrm{C} \mathrm{NMR}\left(75 \mathrm{MHz}, \mathrm{CDCl}_{3}\right)$ : $\delta=23.2,28.8\left(\mathrm{CH}_{2} \mathrm{CH}_{2} \mathrm{CH}\right), 48.1\left(\mathrm{NCH}_{2}\right), 57.6,59.3,60.3(\mathrm{NCH}$, $\left.\mathrm{OCH}_{3}, \mathrm{CHCH}_{2}\right), 77.16\left(\mathrm{CH}_{2} \mathrm{O}\right), 86.3(\mathrm{CHC} \equiv \mathrm{C}), 87.7(\mathrm{CHC} \equiv \mathrm{C})$, 123.5 (ArC), 127.4, 128.1, 128.2, 128.3, 128.4, $131.9(10 \times \mathrm{ArCH})$, 139.9 (ArC) ppm. IR (neat): $\tilde{v}=3059,3028,2871,1598,1489$, 1448, 1104, 1070, 754, 725, $690 \mathrm{~cm}^{-1}$. MS $(70 \mathrm{eV}): \mathrm{m} / \mathrm{z}(\%)=305$ (0.20) $[\mathrm{M}]^{+}, 261$ (16), 260 (82), 192 (54), 191 (100), 189 (36), 165 (12). HRMS (EI): $\mathrm{m} / z$ calcd. for $\mathrm{C}_{21} \mathrm{H}_{23} \mathrm{NO} 305.1780$; found 305.1785 .

(2R)-2-(Methoxymethyl)-1-[(3R)-1-phenyldodec-1-yn-3-yl]pyrrolidine (4gia): Diastereoisomer mixture (10:1). Major diastereoisomer: Yellow oil. $R_{\mathrm{f}}=0.16$ (hexane/EtOAc 9:1). $[\alpha]_{\mathrm{D}}^{20}=71.9(c=1.0$, $\left.\mathrm{CHCl}_{3}\right) \cdot t_{\mathrm{R}}=18.53 .{ }^{1} \mathrm{H}$ NMR $\left(400 \mathrm{MHz}, \mathrm{CDCl}_{3}\right): \delta=0.88(\mathrm{t}, J=$ $\left.6.8 \mathrm{~Hz}, 3 \mathrm{H}, \mathrm{CH}_{3} \mathrm{CH}_{2}\right), 1.22-1.37,1.39-1.95(2 \times \mathrm{m}, 20 \mathrm{H}$, $\left.10 \times \mathrm{CH}_{2}\right), 2.74\left(\mathrm{q}, J=8.4 \mathrm{~Hz}, 1 \mathrm{H}, \mathrm{NCH}_{\mathrm{A}} \mathrm{H}_{\mathrm{B}}\right), 2.89-2.97(\mathrm{~m}, 1$ $\left.\mathrm{H}, \mathrm{NCH}_{\mathrm{A}} H_{\mathrm{B}}\right), 3.07-3.16\left(\mathrm{~m}, 1 \mathrm{H}, \mathrm{CHCH}_{2} \mathrm{O}\right), 3.28-3.44(\mathrm{~m}, 2 \mathrm{H}$, $\left.\mathrm{CH}_{2} \mathrm{O}\right), 3.37\left(\mathrm{~s}, 3 \mathrm{H}, \mathrm{CH}_{3} \mathrm{O}\right), 3.90(\mathrm{t}, J=7.4 \mathrm{~Hz}, 1 \mathrm{H}, \mathrm{NCH})$, 7.25-7.31, 7.39-7.45 (2× m, 5 H, ArH) ppm. ${ }^{13} \mathrm{C} \mathrm{NMR}(100 \mathrm{MHz}$, $\left.\mathrm{CDCl}_{3}\right): \delta=14.3\left(\mathrm{CH}_{3} \mathrm{CH}_{2}\right), 22.8,23.3,26.9,28.5,29.5,29.6,29.7$, $32.1, \quad 35.3,47.8\left(11 \times \mathrm{CH}_{2}\right), \quad 53.9(\mathrm{NCH}), \quad 59.3\left(\mathrm{OCH}_{3}\right), 60.6$ $\left(\mathrm{CHCH}_{2} \mathrm{O}\right), 76.5\left(\mathrm{CH}_{2} \mathrm{O}\right), 85.2(\mathrm{CHC} \equiv \mathrm{C}), 88.9(\mathrm{CHC} \equiv \mathrm{C}), 123.7$ (ArC), 127.9, 128.3, $131.9(5 \times \mathrm{ArCH}) \mathrm{ppm} . \mathrm{IR}$ (neat): $\tilde{v}=3055$, 3035, 2922, 2853, 1597, 1488, 1457, 1441, 1106, 754, 722, $690 \mathrm{~cm}^{-1}$. MS (70 eV): $m / z(\%)=355(0.19)[\mathrm{M}]^{+}, 311(29), 310(100), 229$ (10), 228 (65), 143 (13), 129 (16), 128 (20), 117 (19), 115 (28), 95 (13), 91 (26), 70 (49). HRMS (EI): $m / z$ calcd. for $\mathrm{C}_{24} \mathrm{H}_{37} \mathrm{NO}$ 355.2875 ; found 355.2895 .

1-(1-Deuterio-1,3-diphenylprop-2-yn-1-yl)piperidine $\quad$ (D $\left._{1}-4 a a a\right):{ }^{[33]}$ Yellow solid. $R_{\mathrm{f}}=0.42$ (hexane/EtOAc 9:1); m.p. $55.7-57.6^{\circ} \mathrm{C} . t_{\mathrm{R}}$ $=16.82 .{ }^{1} \mathrm{H}$ NMR $\left(300 \mathrm{MHz}, \mathrm{CDCl}_{3}\right): \delta=1.30-1.42(\mathrm{~m}, 2 \mathrm{H}$, $\left.\mathrm{CH}_{2} \mathrm{CH}_{2} \mathrm{CH}_{2} \mathrm{~N}\right), 1.42-1.62\left(\mathrm{~m}, 4 \mathrm{H}, 2 \times \mathrm{CH}_{2} \mathrm{CH}_{2} \mathrm{~N}\right), 2.49(\mathrm{t}, \mathrm{J}=$ $\left.5.3 \mathrm{~Hz}, 4 \mathrm{H}, 2 \times \mathrm{NCH}_{2}\right), 7.16-7.32(\mathrm{~m}, 6 \mathrm{H}, 6 \times \mathrm{ArH}), 7.40-7.49$ (m, $2 \mathrm{H}, 2 \times \mathrm{ArH}), 7.52-7.60(\mathrm{~m}, 2 \mathrm{H}, 2 \times \mathrm{ArH}) \mathrm{ppm} .{ }^{13} \mathrm{C} \mathrm{NMR}$ $\left(75 \mathrm{MHz} \mathrm{CDCl}_{3}\right): \delta=24.6,26.3,50.8\left(5 \times \mathrm{CH}_{2}\right), 62.1\left(\mathrm{t},{ }^{1} J_{\mathrm{C}, \mathrm{D}}=\right.$ $84 \mathrm{~Hz}, \mathrm{NCD}), 86.1(\mathrm{CHC} \equiv \mathrm{C}), 88.0(\mathrm{CHC} \equiv \mathrm{C}), 123.5$ (ArC), 127.6, 128.2, 128.4, 128.7, $131.9(10 \times \mathrm{ArCH}), 138.6(\mathrm{ArC}) \mathrm{ppm}$. IR (neat): $\tilde{v}=3052,3016,2934,2923,2366,1953,1596,1487,1446$, 1103, 757, 718, $693 \mathrm{~cm}^{-1}$. MS $(70 \mathrm{eV}): \mathrm{m} / \mathrm{z}(\%)=277(10)$ $[\mathrm{M}+1]^{+}, 276(50)[\mathrm{M}]^{+}, 275(22), 200(26), 199(100), 193(43)$, 192 (100), 191 (12), 190 (40), 189 (11), 166 (12), 116 (17).

General Procedure for the $\mathrm{KA}^{2}$ Coupling Catalyzed by $\mathrm{CuNPs} / \mathrm{TiO}_{2}$ : Cyclohexanone $(\mathbf{1 k}, 0.1 \mathrm{~mL}, 1.0 \mathrm{mmol})$, an amine $2(1.0 \mathrm{mmol})$, and phenylacetylene (3a, $0.1 \mathrm{~mL}, 1.0 \mathrm{mmol})$ were placed in a reactor tube containing $\mathrm{CuNPs} / \mathrm{TiO}_{2}(20 \mathrm{mg}$, ca. $0.5 \mathrm{~mol}-\%)$ and $\mathrm{CH}_{2} \mathrm{Cl}_{2}(2 \mathrm{~mL})$. The reaction mixture was warmed to $70^{\circ} \mathrm{C}$ without exclusion of air and monitored by TLC and/or GLC until total conversion of the starting materials. EtOAc $(2 \mathrm{~mL})$ was added to the resulting mixture, followed by filtration through celite and washing with additional EtOAc $(4 \mathrm{~mL})$. The crude reaction product was purified by column chromatography (silica gel, hexane/EtOAc) to give the corresponding pure propargylamines $4 \mathrm{kaa}$ and $4 \mathrm{kea}$

1-[1-(Phenylethynyl)cyclohexyl]piperidine (4kaa): ${ }^{[24]}$ Pale yellow solid. $R_{\mathrm{f}}=0.15$ (hexane/EtOAc 9:1); m.p. $35.5-38.9^{\circ}$ C. $t_{\mathrm{R}}=15.99$. ${ }^{1} \mathrm{H}$ NMR $\left(300 \mathrm{MHz}, \mathrm{CDCl}_{3}\right.$ ): $\delta=1.07-1.79,1.99-2.15,3.58-3.78$ 
$\left(3 \times \mathrm{m}, \quad 20 \mathrm{H}, \quad 10 \times \mathrm{CH}_{2}\right), \quad 7.21-7.34, \quad 7.38-7.48(2 \times \mathrm{m}, \quad 5 \mathrm{H}$, $5 \times \mathrm{ArCH}) \mathrm{ppm} .{ }^{13} \mathrm{C} \mathrm{NMR}\left(75 \mathrm{MHz}, \mathrm{CDCl}_{3}\right): \delta=23.2,24.9,25.9$, $26.8, \quad 35.9, \quad 47.3\left(10 \times \mathrm{CH}_{2}\right), \quad 59.4(\mathrm{NC}), \quad 86.2(\mathrm{C} \equiv C A r), 90.9$ $(C \equiv \mathrm{CAr}), 123.9$ (ArC), 127.7, 128.3, $131.8(5 \times \mathrm{ArCH}) \mathrm{ppm} . \mathrm{IR}$ (neat): $\tilde{v}=3055,2986,2920,2851,1709,1488,1443,1291,1092$, $759,692 \mathrm{~cm}^{-1}$. MS $(70 \mathrm{eV}): \mathrm{m} / z(\%)=267(50)[\mathrm{M}]^{+}, 266(20), 253$ (15), 252 (80), 238 (25), 225 (41), 224 (100), 211 (15), 210 (41), 196 (10), 190 (27), 155 (15), 142 (10), 141 (43), 128 (25), 127 (17), 115 (40), 91 (11), 84 (23).

$N$-Benzyl- $N$-methyl-1-(phenylethynyl)cyclohexanamine (4kea): Pale yellow oil. $R_{\mathrm{f}}=0.67$ (hexane/EtOAc 9:1). $t_{\mathrm{R}}=18.23 .{ }^{1} \mathrm{H} \mathrm{NMR}$ $\left(400 \mathrm{MHz}, \mathrm{CDCl}_{3}\right): \delta=1.24-1.42,1.56-1.83,2.03-2.14(3 \times \mathrm{m}, 10$ $\left.\mathrm{H}, 5 \times \mathrm{CH}_{2}\right), 2.20\left(\mathrm{~s}, 3 \mathrm{H}, \mathrm{CH}_{3}\right), 3.68\left(\mathrm{~s}, 2 \mathrm{H}, \mathrm{NCH}_{2}\right), 7.20-7.25$ (m, 1 H, ArH), 7.26-7.35 (m, 5 H, 5×ArH), 7.36-7.41 (m, $2 \mathrm{H}$, $2 \times \mathrm{ArH}), 7.45-7.52(\mathrm{~m}, 2 \mathrm{H}, 2 \times \mathrm{ArH}) \mathrm{ppm} .{ }^{13} \mathrm{C} \mathrm{NMR}(100 \mathrm{MHz}$, $\left.\mathrm{CDCl}_{3}\right): \delta=23.0,25.9,36.8,55.8\left(6 \times \mathrm{CH}_{2}\right), 35.5\left(\mathrm{CH}_{3}\right), 59.2(\mathrm{NC})$, 85.66 ( $\mathrm{C} \equiv C \mathrm{Ar}), 90.89$ ( $C \equiv \mathrm{CAr}), 123.9$ (ArC), 126.7, 127.8, 128.3, 128.4, 128.9, $131.9(10 \times \mathrm{ArCH}), 141.3(\mathrm{ArC}) \mathrm{ppm}$. IR (neat): $\tilde{\mathrm{v}}=$ 3028, 2929, 2853, 1597, 1489, 1443, 1290, 1057, 754, 735, $690 \mathrm{~cm}^{-1}$. MS $(70 \mathrm{eV}): m / z(\%)=303(23)[\mathrm{M}]^{+}, 302(11), 288(38), 274(11)$, 261 (23), 260 (100), 247 (21), 246 (44), 226 (14), 142 (19), 141 (14), 128 (13), 127 (12), 115 (31), 102 (23), 91 (83), 77 (10), 68 (10), 65 (11). HRMS (EI): $\mathrm{m} / z$ calcd. for $\mathrm{C}_{22} \mathrm{H}_{25} \mathrm{~N}$ 303.1987; found 303.1989 .

Supporting Information (see footnote on the first page of this article): TEM micrograph and size distribution of the $\mathrm{CuNPs} / \mathrm{TiO}_{2}$ catalyst; ${ }^{1} \mathrm{H}$ and ${ }^{13} \mathrm{C}$ NMR spectra of the propargylamines 4 .

\section{Acknowledgments}

This work was generously supported by the Spanish Ministerio de Ciencia e Innovación (MICINN) (grant numbers CTQ2007-65218, CTQ2011-24151), Consolider Ingenio (grant number 2010CSD2007-00006), the Generalitat Valenciana (grant number PROMETEO/2009/039), and Fondos Europeos para el Desarrollo Regional (FEDER). Y. M. and M. J .A. acknowledge the ISO of the Universidad de Alicante for a grant. The authors thank MEDALCHEMY S. L. for a gift of chemicals.

[1] a) F. Xiao, Y. Chen, Y. Liu, J. Wang, Tetrahedron 2008, 64, 2755-2761; b) D. Shibata, E. Okada, J. Molette, M. Médebielle, Tetrahedron Lett. 2008, 49, 7161-7164; c) Y. Yamamoto, H. Hayashi, T. Saigoku, H. Nishiyama, J. Am. Chem. Soc. 2005, 127, 10804-10805; d) D. F. Harvey, D. M. Sigano, J. Org. Chem. 1996, 61, 2268-2272; e) B. Yan, Y. Liu, Org. Lett. 2007, 9, 4323-4326; f) E.-S. Lee, H.-S. Yeom, J.-H. Hwang, S. Shin, Eur. J. Org. Chem. 2007, 3503-3507.

[2] For some recent examples, see: a) C. Jiang, M. Xu, S. Wang, H. Wang, Z.-J. Yao, J. Org. Chem. 2010, 75, 4323-4325; b) F. J. Fañanás, T. Arto, A. Mendoza, F. Rodríguez, Org. Lett. 2011, 13, 4184-4187; c) T. S. Symeonidis, M. G. Kallitsakis, K. E. Litinas, Tetrahedron Lett. 2011, 52, 5452-5455.

[3] See, for instance: a) A. Hoepping, K. M. Johnson, C. George, J. Flippen-Anderson, A. P. Kozikowski, J. Med. Chem. 2000, 43, 2064-2071; b) B. Jiang, M. Xu, Angew. Chem. 2004, 116, 2597; Angew. Chem. Int. Ed. 2004, 43, 2543-2546; c) J. J. Fleming, J. Du Bois, J. Am. Chem. Soc. 2006, 128, 3926-3927.

[4] a) C. W. Olanow, Neurology 2006, 66, S69-S79; b) M. Naoi, W. Maruyama, H. Yi, Y. Akao, Y. Yamaoka, M. ShamotoNagai, J. Neural Transm. 2007, 72, 121-131.

[5] a) I. E. Kopka, Z. A. Fataftah, M. W. Rathke, J. Org. Chem. 1980, 45, 4616-4622; b) S. Czernecki, J.-M. Valéry, J. Car- bohydr. Chem. 1990, 9, 767-770; c) I. Imada, M. Yuasa, I. Nakamura, S.-I. Murahashi, J. Org. Chem. 1994, 59, 2282-2284.

[6] For reviews, see: a) R. Bloch, Chem. Rev. 1998, 98, 1407-1438; b) V. V. Kouznetsov, L. Y. Vargas Méndez, Synthesis 2008, 491506; c) G. Blay, A. Monleón, J. R. Pedro, Curr. Org. Chem. 2009, 13, 1498-1539.

[7] For reviews, see: a) C. Wei, Z. Li, C.-J. Li, Synlett 2004, 1472 1483; b) L. Zani, C. Bolm, Chem. Commun. 2006, 4263-4275; c) C.-J. Li, Acc. Chem. Res. 2010, 43, 581-590; d) W.-J. Yoo, L. Zhao, C.-J. Li, Aldrichim. Acta 2011, 44, 43-51.

[8] For recent reviews and monographs, see: a) Nanoparticles and Catalysis (Ed.: D. Astruc), Wiley-VCH, Weinheim, Germany, 2008; b) M. Kidwai, in: Handbook of Green Chemistry (Eds.: P. T. Anastas, R. H. Crabtree), Wiley-VCH, Weinheim, Germany, 2009, vol. 2, pp. 81-92; c) N. Yan, C. Xiao, Y. Kou, Coord. Chem. Rev. 2010, 254, 1179-1218; d) V. Polshettiwar, R. S. Varma, Green Chem. 2010, 12, 743-754.

[9] For recent reviews, see: a) J. Sun, X. Bao, Chem. Eur. J. 2008, 14, 7478-7488; b) R. J. White, R. V. Luque, L. Budarin, J. H. Clark, D. J. Macquarrie, Chem. Soc. Rev. 2009, 38, 481-494; c) J. M. Campelo, D. Luna, F. Luque, J. M. Marinas, A. A. Romero, ChemSusChem 2009, 2, 18-45; d) L. De Rogatis, M. Cargnello, V. Gombac, B. Lorenzut, T. Montini, P. Fornasiero, ChemSusChem 2010, 3, $24-42$.

[10] a) M. Kidwai, V. Bansal, N. K. Mishra, A. Kumar, S. Mozumdar, Synlett 2007, 1581-1584; b) M. Lakshmi Kantam, S. Laha, J. Yadav, S. Bhargava, Tetrahedron Lett. 2008, 49, 3083-3086.

[11] For reviews, see: a) F. Alonso, G. Radivoy, M. Yus, Russ. Chem. Bull. Int. Ed. 2003, 52, 2563-2576; b) F. Alonso, M. Yus, Chem. Soc. Rev. 2004, 33, 284-293; c) F. Alonso, M. Yus, Pure Appl. Chem. 2008, 80, 1005-1012; d) F. Alonso, P. Riente, M. Yus, Acc. Chem. Res. 2011, 44, 379-391.

[12] a) F. Alonso, C. Vitale, G. Radivoy, M. Yus, Synthesis 2003, 443-447; b) F. Alonso, Y. Moglie, G. Radivoy, C. Vitale, M. Yus, Appl. Catal. A: Gen. 2004, 271, 171-176; c) G. Radivoy, F. Alonso, Y. Moglie, C. Vitale, M. Yus, Tetrahedron 2005, 61, 3859-3864.

[13] a) F. Alonso, Y. Moglie, G. Radivoy, M. Yus, Tetrahedron Lett. 2009, 50, 2358-2362; b) F. Alonso, Y. Moglie, G. Radivoy, M. Yus, Eur. J. Org. Chem. 2010, 1875-1884.

[14] a) F. Alonso, Y. Moglie, G. Radivoy, M. Yus, Adv. Synth. Catal. 2010, 352, 3208-3214; b) F. Alonso, Y. Moglie, G. Radivoy, M. Yus, Org. Biomol. Chem. 2011, 9, 6385-6395; c) F. Alonso, Y. Moglie, G. Radivoy, M. Yus, J. Org. Chem. 2011, 76, 8394 8405; d) F. Alonso, Y. Moglie, G. Radivoy, M. Yus, Heterocycles 2012, 84, 1033-1044.

[15] F. Alonso, T. Melkonian, Y. Moglie, M. Yus, Eur. J. Org. Chem. 2011, 2524-2530.

[16] a) K. Tanaka, F. Toda, Chem. Rev. 2000, 100, 1025-1074; b) K. Tanaka, Solvent-free Organic Synthesis, Wiley-VCH, Weinheim, Germany, 2003.

[17] See, for instance: a) T. Murai, F. Asai, J. Org. Chem. 2008, 73, 9518-9521; b) V. K.-Y. Lo, K. K.-Y. Kung, C.-M. Che, J. Organomet. Chem. 2009, 694, 583-591.

[18] For a review, see: L. Durán Pachón, G. Rothenberg, Appl. Organomet. Chem. 2008, 22, 288-299.

[19] See, for instance: L. Shi, Y.-Q. Tu, M. Wang, F.-M. Zhang, C.A. Fan, Org. Lett. 2004, 6, 1001-1003.

[20] a) D. C. Owsley, C. E. Castro, Org. Synth. 1972, 52, 128-131; b) R. J. K. Taylor, Organocopper Reagents. A Practical Approach, Oxford University Press, Oxford, UK, 1994, pp. 41-42.

[21] G. Charlton, P. B. Howes, C. A. Muryn, H. Raza, N. Jones, J. S. G. Taylor, C. Norris, R. McGrath, D. Norman, T. S. Turner, G. Thornton, Phys. Rev. B 2000, 61, 16177-16120.

[22] For a review on the surface science of titanium oxide, see: U. Diebold, Surf. Sci. Rep. 2003, 48, 53-229.

[23] a) O. P. Pereshivko, V. A. Peshkov, E. V. Van der Eycken, Org. Lett. 2010, 12, 2638-2641; b) O. P. Pereshivko, V. A. Peshkov, D. S. Ermolat'ev, S. Van Hove, K. Van Hecke, L. V. Meervelt, E. V. Van der Eycken, Synthesis 2011, 1587-1594. 
[24] M. Cheng, Q. Zhang, X.-Y. Hu, B.-G. Li, J.-X. Ji, A. S. C. Chan, Adv. Synth. Catal. 2011, 353, 1274-1278.

[25] J. Barluenga, F. J. Fañanás, R. Sanz, C. Marcos, M. Trabada, Org. Lett. 2002, 4, 1587-1590.

[26] L. L. Chang, J. Yang, Y. Wei, J. Y. Ying, Adv. Synth. Catal. 2009, 351, 2887-2896.

[27] H.-D. Feng, D. S. Ermolat'ev, G. Song, E. V. Van der Eycken, J. Org. Chem. 2011, 76, 7608-7613.

[28] S. B. Park, H. Alper, Chem. Commun. 2005, 1315-1317.
[29] S. Samai, G. D. Nandi, M. S. Sing, Tetrahedron Lett. 2010, 51, $5555-5558$.

[30] K. Namitharan, K. Pitchumani, Eur. J. Org. Chem. 2010, 411415.

[31] Y. Ju, C.-J. Li, R. S. Varma, QSAR Comb. Sci. 2004, 23, 891894.

[32] D.-Y. Yu, Y.-G. Zhang, Adv. Synth. Catal. 2011, 353, 163-169.

[33] T. Mitamura, A. Ogawa, Org. Lett. 2009, 11, 2045-2048.

Received: January 26, 2012 Published Online: 


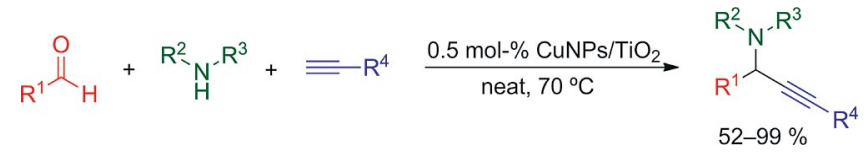

$\mathrm{A}^{3}$ coupling catalyzed by ultrafine copper nanoparticles on titania under solvent-free conditions is described. Some examples of $\mathrm{KA}^{2}$ coupling are also reported. The catalyst is reusable and exhibited better per- formance than commercially available copper catalysts. The participation of copper(I) acetylides in a heterogeneous process has been demonstrated.
M. J. Albaladejo, F. Alonso,* Y. Moglie, M. Yus 1-13

Three-Component Coupling of Aldehydes, Amines, and Alkynes Catalyzed by Oxidized Copper Nanoparticles on Titania

Keywords: Multicomponent reactions / Nanoparticles / Copper / Alkynes / Aldehydes / Amines 